\title{
Article \\ Characterization and Evaluation of Metarhizium spp. (Metsch.) Sorokin Isolates for Their Temperature Tolerance
}

\author{
Viswakethu Velavan ${ }^{1,2, *(1)}$, Rajendran Dhanapal ${ }^{3,4, *} \mathbb{0}$, Govindaraju Ramkumar ${ }^{5}{ }^{\circ}$, Sengodan Karthi ${ }^{5}$, \\ Sengottayan Senthil-Nathan ${ }^{5, *(1)}$, Osmund A. Ndomba ${ }^{6}$ and Eliningaya J. Kweka ${ }^{6,7}$ (i) \\ ICAR-National Bureau of Agricultural Insect Resources, Bengaluru 560024, India \\ Ashoka Trust for Research in Ecology and the Environment (ATREE), Bengaluru 560064, India \\ Adhiparasakthi Horticultural College, Tamil Nadu Agricultural University, Ranipet 632506, India \\ Department of Entomology, Banaras Hindu University, Varanasi 221005, India \\ 5 Sri Paramakalyani Centre for Excellence in Environmental Sciences, Division of Bio pesticides and \\ Environmental Toxicology, Manonmaniam Sundaranar University, Tirunelveli 627012, India; \\ ayvidram@gmail.com (G.R.); karthientomology@gmail.com (S.K.) \\ 6 Division of Livestock and Human Diseases Vector Control, Tropical Pesticides Research Institute, \\ P.O. Box 3024, Arusha 23xxx, Tanzania; ndomba@tpri.go.tz (O.A.N.); pat.kweka@gmail.com (E.J.K.) \\ 7 Department of Medical Parasitology and Entomology, School of Medicine, Catholic University of Health and \\ Allied Sciences, P.O. Box 1464, Mwanza 33xxx, Tanzania \\ * Correspondence: velavan.sv@gmail.com (V.V.); dhanapal.r4@bhu.ac.in (R.D.); senthil@msuniv.ac.in (S.S.-N.)
}

check for

updates

Citation: Velavan, V.; Dhanapal, R.; Ramkumar, G.; Karthi, S.;

Senthil-Nathan, S.; Ndomba, O.A.;

Kweka, E.J. Characterization and

Evaluation of Metarhizium spp.

(Metsch.) Sorokin Isolates for Their Temperature Tolerance. J. Fungi 2022, 8,68. https://doi.org/10.3390/ jof 8010068

Academic Editor: Laurent Dufossé

Received: 30 September 2021

Accepted: 13 December 2021

Published: 10 January 2022

Publisher's Note: MDPI stays neutral with regard to jurisdictional claims in published maps and institutional affiliations.

Copyright: (c) 2022 by the authors. Licensee MDPI, Basel, Switzerland. This article is an open access article distributed under the terms and conditions of the Creative Commons Attribution (CC BY) license (https:// creativecommons.org/licenses/by/ $4.0 /)$

\begin{abstract}
A field survey was done in teak (Tectona grandis F.) forests in South India to explore the entomopathogenic effect of Metarhizium anisopliae (Ascomycota: Sordariomycetes) against teak defoliator, Hyblaea puera (Lepidoptera: Hyblaeidae). About 300 soils and infected insect samples were collected during the survey and thirty-six fungal isolates were isolated from soil and insect samples and characterized. The fungi were cultured on PDAY with dodine and antibiotics. Generally, the EPF culture was incubated at $27^{\circ} \mathrm{C}$ in darkness for 15 days. Virulence of the Entomopathogenic Fungi (EPF) ability to germinate under cold and heat temperatures was assessed in a culture impregnated with conidia. In the experiment, it was found that for the first time Metarhizium quizhouense, Metarhizium robertsii, and Metarhizium majus species caused significantly higher mortality to hosts. These isolates of M. anisopliae, M. robertsii, M. majus, and M. quizhouense were all considered to be effective virulent and environmentally adaptive. The Metarhizium isolates were recommended as effective bio-control agents through the field investigation of teak defoliator Hyblaea puera from South India forest. This study paves the way to utilize the indigenous isolates of EPF for the control of teak defoliator and to combat the pests thatare resistant to insecticide.
\end{abstract}

Keywords: Metarhizium anisopliae; Metarhizium robertsii; Metarhizium majus; Metarhizium quizhouense; chitinase; protease; temperature tolerance; Hyblaea puera

\section{Introduction}

Entomopathogenic fungi (EPF) are widely used as bio-agents against various insect pests in agriculture, forest, other crop pests, and aquatic invertebrates. For about 100 years, myco-insecticides have been established [1] as one of the most promising pest biocontrol options in important insects or other arthropods [2,3]. However, it increases the low growth rate of opportunistic fungi [4-6].

The use of EPF as a pest management tool is affected by many biotic and abiotic factors. During conidia germination, they are affected by enhanced activity of the secondary metabolism [7-11]. Thermotolerance is an important factor that influences the survival, growth, development, and pathogenicity of EPF [12]. The Metarhizium sp., culture showed delayed conidial germination and mycelia growth when it was exposed to lower light $[13,14]$. Conversely, the EPF tolerated heat temperature during mycelia growth, which induces the high-protein metabolism $[15,16]$. 
The EPF isolates have been an asset in pest control because of their contact mode of action, the production of toxins in the insect body. When the conidia makes contact with the insect integument, they can directly penetrate insects' pest bodies through the cuticle degradation enzyme [17-19] by the development of endo-chitinase, chitin deacetylase, chitosanase, alkaline protease, and lipase [20,21], which facilitate infection. In previous studies, it was described that $M$. anisopliae isolates were one of the major virulent entomopathogenic microorganisms that induced large amounts of extracellular enzymes (chitinase, lipase, and protease) for penetrating host cuticles [22,23].

The effect of the biocontrol agents was tested against various insect orders, with the case study being an important forest pest called teak defoliator, Hyblaea puera Cramer (Hyblaeidae). The defoliator is considered as a very serious pest in both forest plantations and natural forests [24]. It is a host specific moth that is native to Southeast Asia [25]. First described by Pieter Cramer, caterpillars of the species have been recently reported to feed on teak and other high value trees [26,27] in India. In vitro screening of an entomopathogenic fungus called Metarhizium spp. was done against Hyblaea puera. Out of the nine isolates of the EPF (Metarhizium sp.), four species of $M$. anisopliae, M. robertsii, M. majus, and M. quizhouense were analyzed by testing conidia produced under light and dark conditions to detect any differences in conidia thermo-tolerances. The best performing EPF isolate was described as being the potential in pest control, which plays an important role in secondary metabolism, caused by several insect groups. In the current research, an investigation of EPF isolates found in forest soils and infected insects and their pathogenicity against teak defoliator was done. This is one of the pioneer experiments investigating a novel way to use $M$. robertsii, $M$. majus, and $M$. quizhouense for the biological control of teak defoliator Hyblaea puera.

\section{Materials and Methods}

\subsection{Fungal Isolates and Culture Conditions}

During the survey, 300 soil samples were collected from 20 different climatic locations of South India, and 16 infected cadavers were collected [28] (Figure 1). The fungus was isolated from the soil using the Galleria bait method. The fungal infected was subsequently purified on Veen's medium containing [29] Dodine, subjected to selective media PDAY supplemented with antibiotics with the following composition (1\% yeast extract $(0.6 \mathrm{~g})$, Chloramphenicol $(100 \mu \mathrm{g} / \mathrm{mL})$, Streptomycin $(50 \mu \mathrm{g} / \mathrm{mL})$, crystal violet $(2 \mathrm{mg})$ in Potato Dextrose Agar with Yeast extract (PDAY), and then incubated at $27 \pm 2{ }^{\circ} \mathrm{C}$ for up to 5 to 14 days with $\mathrm{RH} 80 \%$ to evaluate the fungal viability. EPF isolates were continuously sub-cultured on Sabouraud Dextrose Agar with Yeast extract (SDAY) slants at $28{ }^{\circ} \mathrm{C}$ and maintained at $4{ }^{\circ} \mathrm{C}$. Further, microscopic permanent slide cultures were prepared for the identification of the Metarhizium sp. [30].

\subsection{Insect Culture}

The insect cultures of teak defoliator (Hyblaea puera) were maintained at ICFREInstitute of Wood Science and Technology, Bengaluru, Karnataka, India. The culture was maintained on the natural host plant (teak) for two generations. For establishing the insect culture, larvae were grown on fresh tender teak leaf. The leaves were collected and stored in the plastic box that contained moist filter paper disc. The leaves were changed every 10 days. After establishment of the culture under laboratory conditions, the larvae were maintained on artificial media. The larvae were reared on ingredients of artificial diet (Kabuligram flour, Multivitamin and mineral mixture, Vitamin E, Streptomycin sulphate, Tetracycline hydrochloride, Sorbic acid, Ascorbic acid, and Formaldehyde) under laboratory conditions [31]. Individual larvae were then reared separately in sterilized plastic tubes $(7 \mathrm{~cm} \times 2.5 \mathrm{~cm})$ [25]. The cups were covered with aluminum foil to prevent the larvae from escaping. The culture was maintained at the temperature at $28 \pm 2{ }^{\circ} \mathrm{C}$ and $75 \pm 5 \%$ RH. 


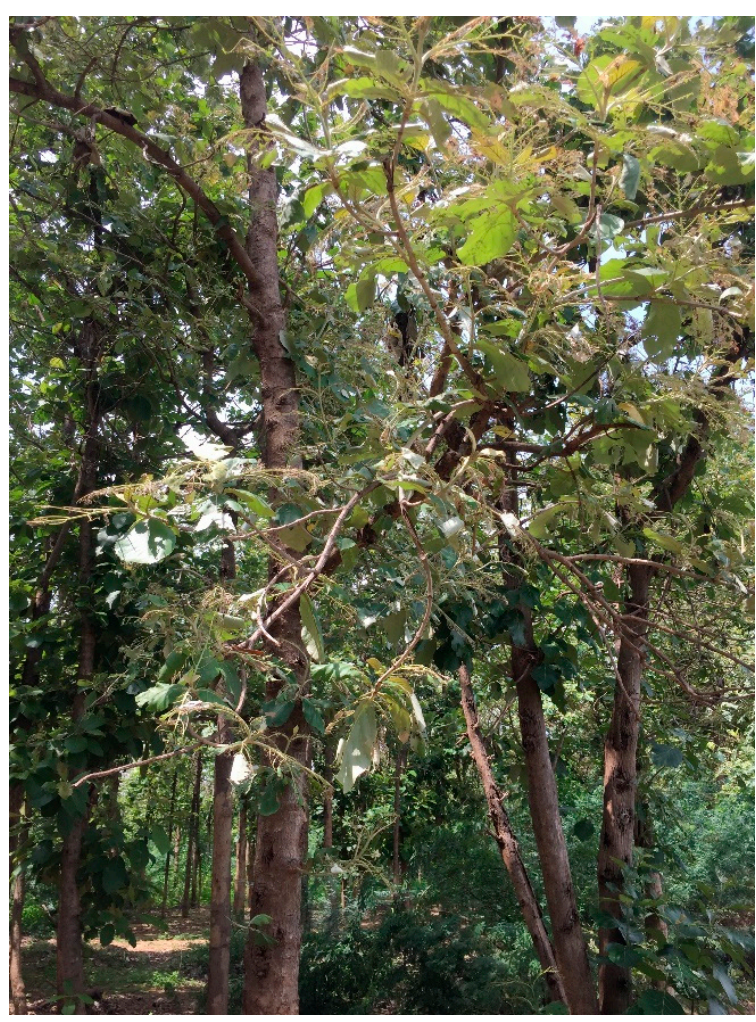

(a)

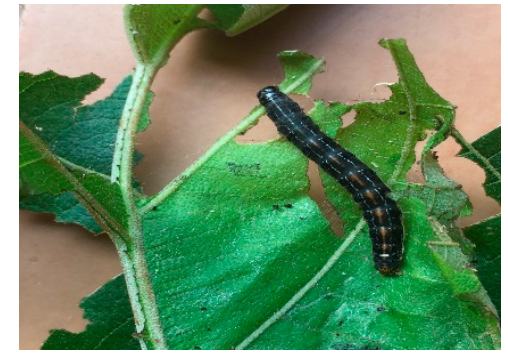

(b)

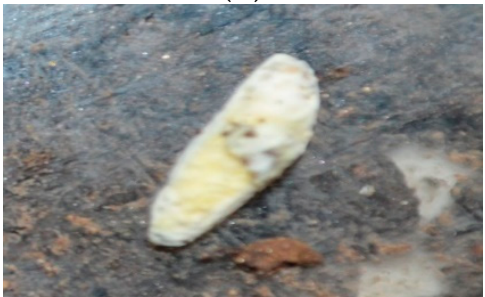

(c)

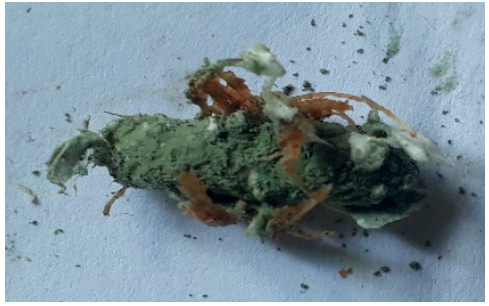

(d)

Figure 1. (a) Teak forest with H. puera infestation in field, (b) H. puera feeding on leaves, (c) Dead larvae showing the symptoms of $M$. quizhouense infection, and (d) Insect mummified covered M. robertsii infected cadaver with spores.

\subsection{Bioassay of Metarhizium spp. against Hyblaea puera}

Out of the 36 isolates that were screened, nine EPF isolates were evaluated through the YPD medium $(0.2 \%$ yeast extract, $1 \%$ peptone, $2 \%$ dextrose with $1 \%$ casein $/ 10 \mathrm{~g}$ chitin purified powder $\left(25 \pm 2{ }^{\circ} \mathrm{C}, 75 \pm 5 \% \mathrm{RH}\right)$ incubated at 15 days post inoculation and some modification in Pontecorvo [32]. Based on the preliminary pathogenicity studies, the virulent isolates of nine Metarhizium sp. were used for the bioassay against 3rd instar larvae of $H$. puera, using for the concentration of $1 \times 10^{3}$ to $1 \times 10^{6}$ conidial $/ \mathrm{mL}$ to determine their pathogenicity. Each experiment was replicated three times. The conidial suspension was prepared using the 15 days old culture by scrapping the mycelial growth in sterile water and then filtering in double layer muslin cloth. The stock conidial suspension was prepared by counting the conidia using the improved Neubauer Heamocytometer. Uniform dispersion of conidial suspension was achieved by adding the wetting agents $(0.2 \%$ Tween-80) to the stock solution. The teak leaf was dipped in the conidial suspension and provided for feeding to the 3rd instars larvae. In each replication, 15 larvae were used. The mortality counts were taken daily for 10 days. The dead larvae were placed on moist filter paper in Petri plates.

\subsection{Production of Cuticle-Degradation Enzymes}

To obtain the insect cuticle, infected 3rd insect larvae of the H. puera cuticles were used. The internal materials of the dead insect larvae were removed and dried to a constant weight in an oven at $80^{\circ} \mathrm{C}$. Then, the exoskeleton was macerated. The resulting powder was sieved and stored at $-20^{\circ} \mathrm{C}$. At the time of experiment, the powder was suspended in an aqueous solution of potassium tetraborate (1\%). The extract was subjected to a flowing steam for $20 \mathrm{~min}$ [33], dried in a sterile-air-flow cabinet to avoid contamination, and inoculated with $50 \mu \mathrm{L}$ distilled water, which contained 5000 conidia. Following incubation 
$(60 \mathrm{~h})$ at $27 \pm 5{ }^{\circ} \mathrm{C}$, the cuticles were checked microscopically to ensure there was no bacterial contamination and enzymes were extracted as described [33]. The cuticle extract was placed on performed enzyme specific medium and incubated at $27^{\circ} \mathrm{C}$ for 15 days after growth of the EPF species.

\subsection{Estimation of Extracellular Enzyme Activity on H. puera}

Among the nine isolates selected, Metarhizium spp. was grown in a selective medium for 12 days as described above. Protease activity was measured using casein as a substrate $0.6 \%(w / v)$. Casein solution (prepared by mixing $6 \mathrm{mg} / \mathrm{mL}$ casein with the reaction mixture) contained $100 \mu \mathrm{L}$ of Tris- $\mathrm{HCl}$ buffer $(20 \mathrm{mM}, \mathrm{pH} 8)$ and was inoculated with $1 \mathrm{~mL}$ of the enzyme at $30{ }^{\circ} \mathrm{C}$ for $10 \mathrm{~min}[22,23]$. A measure of $0.5 \mathrm{~mL}$ of the supernatant was added (1.25 mL of $0.4 \mathrm{M} \mathrm{Na}_{2} \mathrm{CO}_{3}$ and $0.25 \mathrm{~mL}$ of $2 \mathrm{~N}$ Folin). It was then added to $0.4 \mathrm{M}$ trichloroacetic acid (TCA) solution and the absorbance was measured at $650 \mathrm{~nm}$ in a spectrophotometer, which was incubated at $30{ }^{\circ} \mathrm{C}$ for $30 \mathrm{~min}$. The amount of amino acids released was calculated from a standard curve plotted against a range of known concentrations of tyrosine. Afterwards, the product was centrifuged for $5 \mathrm{~min}$ at 10,000 rpm. One unit of enzyme was defined as the amount of enzyme that released $1 \mu \mathrm{g}$ of tyrosine $\mathrm{mL}^{-1}$ of crude enzyme.

Chitinase enzyme activity of the culture supernatant was estimated using the substrate acid-swollen chitin [20,34]. To prepare the acid-swollen chitin, $10 \mathrm{~g}$ of chitin (purified powder from crab shells (HiMedia, Mumbai, Maharashtra) was suspended in $100 \mathrm{~mL}$ of $\mathrm{HCl}(35 \%, w / v)$ and the mixture was stirred at $5 \mathrm{~min}$ intervals for $1 \mathrm{~h}$ at room temperature in a fume hood. One unit of chitins was defined as the amount of enzyme that released $\mathrm{N}$ acetyl D-glucosamine, or $100 \mu \mathrm{L}$ dinitrosalicylic acid was added with incubation for $10 \mathrm{~min}$ inboiling water. Absorbance of the reaction mixture at $582 \mathrm{~nm}$ (A582) was measured after cooling the room temperature [35]. The procedure is described above, and the bioassay was conducted according to [32].

\subsection{Temperature Optimization of Fungal Isolates Growth}

\subsubsection{Effect of Heat Temperature on Relative Germination (RG)}

The relative germination of EPF at high temperature $\left(45^{\circ} \mathrm{C} \& 48^{\circ} \mathrm{C}\right)$ was checked on the 9 virulent isolates of Metarhizium spp., Out of 36 isolates, nine isolates has been found to be virulent isolates. The EPF was cultured on PDAY medium and kept in the dark at $27 \pm 1{ }^{\circ} \mathrm{C}$ for 15 days. Mycelium of the fungus was harvested with a microbiological loop in sterile water and immediately suspended in Tween 80 solution. The suspension was filtered out through double layer muslin cloth to get conidia. The conidial concentration was prepared by counting the conidia under the Neubauer hemocytometer and the concentration of $10^{6}$ conidia/mL was made. The $2 \mathrm{~mL}$ filtered suspension was transferred to a Borosil glass screw cap tube and kept in water bath at $45^{\circ} \mathrm{C}$ and $48{ }^{\circ} \mathrm{C}$ for $5 \pm 1 \mathrm{~min}$. After $2,4,6,8,10,12,24,36,48$, and $60 \mathrm{~h}$ of exposure with $45^{\circ} \mathrm{C}$ and $48^{\circ} \mathrm{C}$, a $20 \mu \mathrm{L}$ aliquot was placed on $4 \mathrm{~mL}$ of medium (PDAY) and one drop of lactophenol methyl blue was added, after which a coverslip was placed on it [36]. The germination was observed at $400 \times$ magnification. For the control, the conidial suspension was not exposed at $45^{\circ} \mathrm{C}$ and $48{ }^{\circ} \mathrm{C}$ temperatures. All of the culture was incubated at $27 \pm 2{ }^{\circ} \mathrm{C}$. The observation was taken on the 300 conidia and the germination percentage was calculated by comparing the germination of the heated conidia with the control [37]. Only germinated isolates were taken for assessment.

\subsubsection{Effect of Cold Temperature on Relative Germination (RG)}

To know the effect of cold temperature $\left(5^{\circ} \mathrm{C}, 10^{\circ} \mathrm{C}\right.$, and $\left.20^{\circ} \mathrm{C}\right)$ on relative germination, the $2 \mathrm{~mL}$ of filtered suspension was transferred to a (Borosil glass) screw cap tube and exposed to cold temperature at $5^{\circ} \mathrm{C}, 10{ }^{\circ} \mathrm{C}$, and $20^{\circ} \mathrm{C}$. After 5,10 , and 15 days of exposure, $20 \mu \mathrm{L}$ of conidial suspension of each isolate was poured on $4 \mathrm{~mL}$ of medium by following 
the procedure that was used for the effect of heat temperature. For the control, the conidia were grown in ambient temperature $\left(28 \pm 2{ }^{\circ} \mathrm{C}\right)$ without exposure to cold temperature [38].

\subsection{Analysis of Results}

Significant mortality of the larvae (percent) was recorded from the bioassay and corrected according to Abbott's formula. Two-way ANOVA was used to compare the effects of the experimental and control treatments on the larval mortality. Prior to statistical analysis, data expressed as proportions were subjected to a regular arc transformation (one way analysis $p<0.001)$. The data were then subjected to analysis of variance (ANOVA), and the means were compared by Tukey test at the $(p<0.001)$ probability level using (Graph was generated using Origin Lab Professional Version 2021b software; URL link: www.OriginLab.com/2021b, accessed on 29 September 2021).

\section{Results}

\subsection{Isolation and Identification of Fungi}

A total 36 isolates were obtained from forest soils and infected cadavers, which were collected from various locations [39]. There were four species of entomopathogenic fungi, viz., M. robertsii, M. quizhouense, M. majus, and M. anisopliae, from the soil and infected cadaver sample (Table 1). At the same time, other entomopathogenic fungi were grown in culture medium but failed to infect the host insects and were, therefore, not taken for further study. Moreover, during the isolation on PDAY culture medium, opportunistic fungi, viz., Aspergillus, Penicillium, Colletotrichum, and Scopulariopsis, were dominant and these fungi were not considered for further study in this identification. All these isolates were molecularly characterized using ribosomal internal transcribed spacer region (ITS) and DNA-directed RNA polymerase II subunit (RPB1) [39], and the Elongation factor 1-alpha $(\mathrm{EP} 1 \alpha)$ genes sequence was analyzed as well, although it could not yet be submitted (NCBI).

Table 1. List of Metarhizium spp. Isolates obtained and sequenced for phylogenetic analysis.

\begin{tabular}{|c|c|c|c|c|c|c|}
\hline \multirow{2}{*}{ Fungi } & \multirow{2}{*}{ Type of Forest } & \multirow{2}{*}{ Source } & \multirow{2}{*}{ Region } & \multirow{2}{*}{$\begin{array}{l}\text { Geographical } \\
\text { Origin }\end{array}$} & \multicolumn{2}{|c|}{ Accession Number } \\
\hline & & & & & ITS & RPB1 \\
\hline M.robertsii ArMz3R & WEF & $\begin{array}{c}\text { Insect(Protaetia } \\
\text { aurichalcea) }\end{array}$ & Aralam & $11^{\prime} 99^{\circ} \mathrm{N} 75^{\prime} 76^{\circ} \mathrm{E}$ & KU983799 & KU680339 \\
\hline M.robertsii ArMz3S & WEF & Insect $(P$. aurichalcea $)$ & Aralam & $11^{\prime} 99^{\circ} \mathrm{N} 75^{\prime} 76^{\circ} \mathrm{E}$ & KU983775 & KU680335 \\
\hline $\begin{array}{l}\text { M.robertsii } \\
\text { ArMz6W }\end{array}$ & WEF & $\begin{array}{c}\text { Insect }(P . \\
\text { aurichalcea) }\end{array}$ & Aralam & $11^{\prime} 99^{\circ} \mathrm{N} 75^{\prime} 76^{\circ} \mathrm{E}$ & KU983797 & KU680341 \\
\hline $\begin{array}{l}\text { M.quizhouense } \\
\text { ArMz1W }\end{array}$ & WEF & $\begin{array}{c}\text { Insect(Eutectona } \\
\text { machaeralis) }\end{array}$ & Aralam & $11^{\prime} 99^{\circ} \mathrm{N} 75^{\prime} 76^{\circ} \mathrm{E}$ & KU870314 & Not yet \\
\hline M.majus VjMz1W & WEF & $\begin{array}{c}\text { Insect(Melolontha } \\
\text { guttigera })\end{array}$ & Coorg & $12^{\prime} 20^{\circ} \mathrm{N} 75^{\prime} 80^{\circ} \mathrm{E}$ & KU983771 & KU680342 \\
\hline $\begin{array}{c}\text { M.anisopliae } \\
\text { WnMz1S }\end{array}$ & WEF & soil & Aralam & $11^{\prime} 60^{\circ} \mathrm{N} 76^{\prime} 08^{\circ} \mathrm{E}$ & KU983788 & KU680323 \\
\hline $\begin{array}{l}\text { M.anisopliae } \\
\text { N1Mz2S }\end{array}$ & MDF & soil & Bengaluru & $12^{\prime} 97^{\circ} \mathrm{N} 77^{\prime} 59^{\circ} \mathrm{E}$ & KU983785 & KU680325 \\
\hline $\begin{array}{c}\text { M.anisopliae } \\
\text { BgMz2S }\end{array}$ & DDF & soil & Bengaluru & $12^{\prime} 80^{\circ} \mathrm{N} 77^{\prime} 57^{\circ} \mathrm{E}$ & KU983780 & KU680320 \\
\hline $\begin{array}{l}\text { M.anisopliae } \\
\text { DhMz4R }\end{array}$ & MDF & soil & Palakkad & $10^{\prime} 77^{\circ} \mathrm{N} 76^{\prime} 65^{\circ} \mathrm{E}$ & KU983784 & KU680328 \\
\hline
\end{tabular}

Wet Evergreen Forest (WEF), Moist Deciduous (MDF), and Dry Deciduous Forest (DDF). ITS—ribosomal internal transcribed spacer; RPB1-DNA-directed RNA polymerase II subunit. 


\subsection{Bioassay Tested Metarhiziumsp. Isolates against H. puera}

Overall, these results revealed that the three isolates of M. anisopliae (DhMz4R), M. quizhouense (ArMz1W), and M. majus (VjMz1W) showed higher mortality, viz., $94.4 \pm 2.03$, $92 \pm 4.19$, and $90.8 \pm 3.2$ per cent, respectively, against the larvae of $H$. puera. However, there was no significant difference in the pathogenicity of isolates during 10 days after treatment (Figure 2). At 8 days after treatment, there was a significant difference in the pathogenicity among the isolates. The isolate of M. quizhouense (ArMz1W) showed significant percent mortality against the 3 rd instar larvae of H. puera (Figure 2).

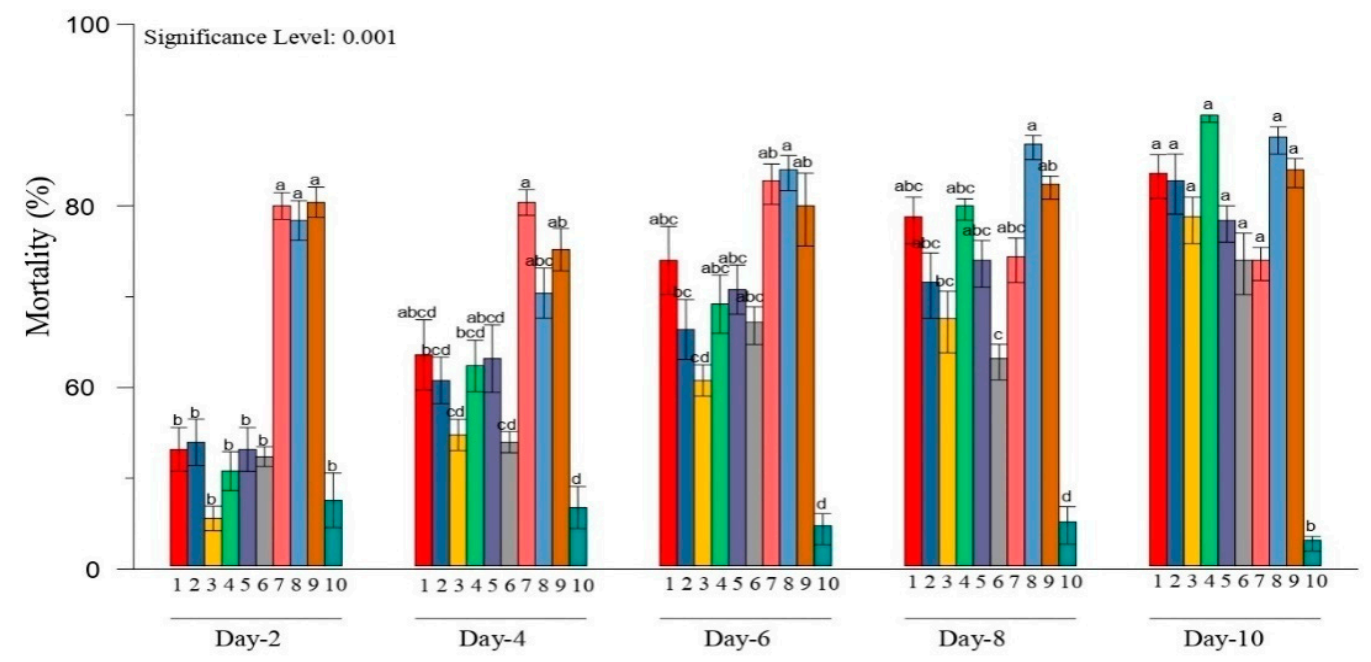

Figure 2. Virulence of entomopathogenic fungi isolates against the $H$. puera larvae, and statistical differences are shown by different letters (Tukey's test, $p<0.001$ ). (1-4) M. anisopliae (WnMz1S, NIMz2S, BgMz2S, DhMz4R); (5-7) M. robertsii (ArMz3R, ArMz3S, ArMz6W); (8), M. quizhouense (ArMz1W); (9), M. majus (VjMz1W); (10), Control.

\subsection{Evaluation of Metarhizium sp. Isolates Effected Non-Extracellur Enzymes}

The four species of Metarhizium sp., viz., M. robertsii, M. quizhouense, M. majus and M. anisopliae, were previously screened for pathogenicity [28]. The larvae were evaluated in four concentrations spanning from $1 \times 10^{3}$ to $1 \times 10^{6}$ conidia $/ \mathrm{mL}$ (Table 2). It was observed that the mortality was increased as the concentration increased. Protease response during the observation $\left(1 \times 10^{6}\right.$ conidia/mL), M. robertsii (ArMz3S), M. quizhouense (ArMz1W), M. majus (VjMz1W), M.anisopliae (WnMz1S), and M. anisopliae (NlMz2S)showed significantly higher pathogenicity and their percent morality was on par with each other (27.807, $27.063,27.489,27.943$, and 27.618 percent $)(C D=1.050)$. The lowest percent mortality was shownby the M. anisopliae (BgMz2S) isolate.

Table 2. Virulence of Entomopathogenic fungi isolates against the third-instar larvae of H. puera.

\begin{tabular}{|c|c|c|c|c|c|c|c|c|}
\hline \multirow{2}{*}{ Isolates Name } & \multicolumn{4}{|c|}{$\%$ Mortality of $H$. puera Due Protease } & \multicolumn{4}{|c|}{$\%$ Mortality of H. puera Due Chitinase } \\
\hline & $10^{3 *}$ & $10^{4 *}$ & $10^{5 *}$ & $10^{6 *}$ & $10^{3 *}$ & $10^{4 *}$ & $10^{5 *}$ & $10^{6 *}$ \\
\hline M. robertsii ArMz3R & 8.499 ab & $13.400 \mathrm{ab}$ & $24.121^{\mathrm{a}}$ & $26.929^{b}$ & $9.862^{b}$ & $12.826^{\mathrm{e}}$ & 19.355 de & $23.619^{c}$ \\
\hline M. robertsii ArMz3S & $11.465^{\mathrm{a}}$ & $14.771^{\mathrm{a}}$ & $24.539^{a}$ & $27.807^{\mathrm{a}}$ & $8.879^{b}$ & $19.594^{\mathrm{a}}$ & $20.270^{\mathrm{cd}}$ & $27.618^{a b}$ \\
\hline M. robertsii ArMz6W & $8.702^{a b}$ & $13.285^{\mathrm{ab}}$ & $22.481^{\mathrm{b}}$ & $26.371^{b}$ & $8.350^{b}$ & $15.728^{c d}$ & $20.518^{c d}$ & $27.489 \mathrm{ab}$ \\
\hline M. quizhouense ArMz1W & $8.280^{a b}$ & $14.503^{a}$ & $24.850^{\mathrm{a}}$ & $27.063^{a}$ & $13.241^{a}$ & $19.575^{\mathrm{a}}$ & $23.607^{a b}$ & $28.214^{\mathrm{a}}$ \\
\hline M. majus VjMz1W & $5.476^{\mathrm{bc}}$ & $13.067^{a b}$ & $22.160^{b c}$ & $27.489^{a}$ & $13.241^{a}$ & $19.234^{\mathrm{ab}}$ & $25.673^{a}$ & $27.083^{a b}$ \\
\hline M. anisopliae WnMz1S & $3.965^{c}$ & $13.341 \mathrm{ab}$ & $21.524^{\mathrm{cd}}$ & $27.943^{\mathrm{a}}$ & $8.813^{\mathrm{b}}$ & 12.109 ef & $24.057 \mathrm{ab}$ & $26.648^{b}$ \\
\hline M. anisopliae BgMz2S & $2.639 \mathrm{~cd}$ & $12.419 \mathrm{abc}$ & $19.333^{\mathrm{e}}$ & $23.333^{f}$ & $8.879^{\mathrm{b}}$ & $14.111^{\mathrm{de}}$ & $19.965^{\mathrm{de}}$ & $22.704^{\mathrm{c}}$ \\
\hline
\end{tabular}


Table 2. Cont.

\begin{tabular}{|c|c|c|c|c|c|c|c|c|}
\hline \multirow{2}{*}{ Isolates Name } & \multicolumn{4}{|c|}{$\%$ Mortality of $H$. puera Due Protease } & \multicolumn{4}{|c|}{$\%$ Mortality of $H$. puera Due Chitinase } \\
\hline & $10^{3 *}$ & $10^{4 *}$ & $10^{5 *}$ & $10^{6 *}$ & $10^{3 *}$ & $10^{4 *}$ & $10^{5 *}$ & $10^{6 *}$ \\
\hline M. anisopliae NIMz2S & $2.573^{\mathrm{cd}}$ & $12.947^{\mathrm{ab}}$ & $20.997^{d}$ & $27.618^{a}$ & $8.501^{b}$ & $14.019 \mathrm{de}$ & 17.910 ef & $26.916^{b}$ \\
\hline M. anisopliae DhMz4R & $4.151^{\mathrm{c}}$ & $10.899 \mathrm{bc}$ & $19.218^{\mathrm{e}}$ & $25.284^{\mathrm{e}}$ & $9.912^{b}$ & $17.039 \mathrm{bc}$ & $22.265^{b c}$ & $26.772^{b}$ \\
\hline Control & $0.573^{d}$ & $1.440^{\mathrm{d}}$ & $6.957^{\mathrm{f}}$ & $10.184^{\mathrm{g}}$ & $1.606^{c}$ & $2.639 \mathrm{~g}$ & $4.151^{\mathrm{g}}$ & $9.873^{d}$ \\
\hline SE & 18.701 & 7.849 & 3.186 & 2.348 & 27.273 & 11.393 & 8.032 & 3.159 \\
\hline $\mathrm{CD}(0.01)$ & 4.459 & 2.478 & 1.184 & 1.050 & 4.400 & 3.019 & 2.897 & 1.414 \\
\hline $\mathrm{CD}(0.05)$ & 3.072 & 1.849 & 0.883 & 0.783 & 3.282 & 2.252 & 2.161 & 1.055 \\
\hline
\end{tabular}

Within the same column, mean \pm S.E.M. followed by different letters are significantly different from each other followed by adjusted Tukey test. ${ }^{*}$ Spores $/ \mathrm{mL}$.

The percent mortality caused by different isolates of entomopathogenic fungi due to chitinase was significantly different $(C D=1.414)$. M. quizhouense (ArMz1W) isolate showed highest percent mortality (28.214\%), followed by ArMz3S (27.618\%) and ArMz6W (27.489\%) at $10^{6}$ conidia/mL (Table 2$)$.

The results indicate that $M$. quizhouense (ArMz1W) was most effective in causing the mortality against the 3rd instar larvae of $H$. puera through the production of chitinase and protease.

\subsection{Extracellur Protease Enzymes Activity}

During the experiment, the effect of protease enzymes on virulence levels was evaluated. Protease activities reached a maximum after 5 days of incubation and decreased thereafter for the control. The protease activity of nine isolates of Metarhizium sp. was significantly different from each other (Table 3; Figure 3). Through comparative analysis, the present study demonstrated that the isolates, viz., M. quizhouense (ArMz1W) and M. robertsii (ArMz6W), showed the highest significant on par protease activity compared with other isolates $(22.4 \pm 1.0$ and $22 \pm 0.7 \mathrm{U} / \mathrm{mL})$, respectively, whereas the isolate of M. anisopliae (BgMz2S) showed the lowest protease activity.

Table 3. Activities of protease $(\mathrm{U} / \mathrm{mL})$ (Mean $\pm \mathrm{SE}$ ) in the liquid culture media of the entomopathogenic fungi in the presence of $H$. puera cuticle.

\begin{tabular}{|c|c|c|c|c|c|c|}
\hline \multirow{2}{*}{ Isolates } & \multicolumn{5}{|c|}{ Proteases Enzyme Activity (U/mL) } & \multirow{2}{*}{$\begin{array}{c}\text { Compatative } \\
\text { Analysis }\end{array}$} \\
\hline & Day-1 & Day-2 & Day-3 & Day-4 & Day-5 & \\
\hline ArMz3R & $2.2 \pm 0.2^{c}$ & $6.2 \pm 0.6^{b c}$ & $12.6 \pm 0.6^{\mathrm{ab}}$ & $17.4 \pm 1.1^{\mathrm{a}}$ & $20.6 \pm 1.5^{a}$ & $20.6 \pm 3.4^{b}$ \\
\hline ArMz3S & $4.8 \pm 1.3^{c}$ & $8.8 \pm 1.2^{b c}$ & $14 \pm 0.7^{\mathrm{ab}}$ & $18.8 \pm 0.9^{a}$ & $21.2 \pm 0.8^{a}$ & $21.2 \pm 1.7^{\mathrm{ab}}$ \\
\hline ArMz6W & $5 \pm 0.7^{\mathrm{c}}$ & $12.2 \pm 0.8^{b c}$ & $16.6 \pm 1.3^{\mathrm{ab}}$ & $20 \pm 1^{a b}$ & $22.4 \pm 1.0^{a}$ & $22.4 \pm 3.3^{a}$ \\
\hline ArMz1W & $5.4 \pm 1.0^{c}$ & $10.8 \pm 1.7^{b c}$ & $14.8 \pm 1.5^{\mathrm{ab}}$ & $19.8 \pm 1.0^{\mathrm{a}}$ & $22 \pm 0.7^{a}$ & $22.0 \pm 2.4^{\mathrm{a}}$ \\
\hline VjMz1W & $5.6 \pm 1.2^{c}$ & $10.8 \pm 1.4^{b c}$ & $12.8 \pm 1.5^{\mathrm{abc}}$ & $15 \pm 1.41^{\mathrm{ab}}$ & $20.6 \pm 1.5^{a}$ & $20.6 \pm 3.1^{b}$ \\
\hline WnMz1S & $4.6 \pm 0.9^{c}$ & $7.8 \pm 0.8^{b c}$ & $12.2 \pm 1.0^{\mathrm{abc}}$ & $14.2 \pm 1.3^{\mathrm{ab}}$ & $17.8 \pm 0.8^{a}$ & $17.8 \pm 3.1^{\mathrm{cd}}$ \\
\hline NlMz2S & $4.4 \pm 1.2^{b}$ & $6 \pm 1.3^{b}$ & $10.4 \pm 1.7^{\mathrm{ab}}$ & $14.6 \pm 1.6^{\mathrm{a}}$ & $16.6 \pm 1.6^{a}$ & $16.6 \pm 1.7^{\mathrm{de}}$ \\
\hline BgMz2S & $2.6 \pm 0.6^{c}$ & $5.6 \pm 0.6^{b c}$ & $8.4 \pm 0.92^{a b c}$ & $11 \pm 1.30^{a b}$ & $16.4 \pm 1.2^{a}$ & $16.4 \pm 2.2^{\mathrm{e}}$ \\
\hline DhMz4R & $4 \pm 0.8^{c}$ & $8 \pm 1.1^{b c}$ & $10.4 \pm 1.6^{\mathrm{abc}}$ & $13.2 \pm 1.3^{\mathrm{ab}}$ & $18.2 \pm 1.7^{a}$ & $18.2 \pm 1.4^{\mathrm{c}}$ \\
\hline Control & $0.4 \pm 0.2^{a}$ & $0.2 \pm 0.2^{a}$ & $0.4 \pm 0.24^{\mathrm{a}}$ & $0.2 \pm 0.2^{a}$ & $0.4 \pm 0.2^{a}$ & $0.4 \pm 0.9^{\mathrm{f}}$ \\
\hline $\mathrm{CV}$ & & & & & & 5.714 \\
\hline $\mathrm{CD}(0.01)$ & & & & & & 1.745 \\
\hline
\end{tabular}

Within the same row, mean \pm S.E.M. followed by different letters are significantly different from each other followed by adjusted Tukey test. 


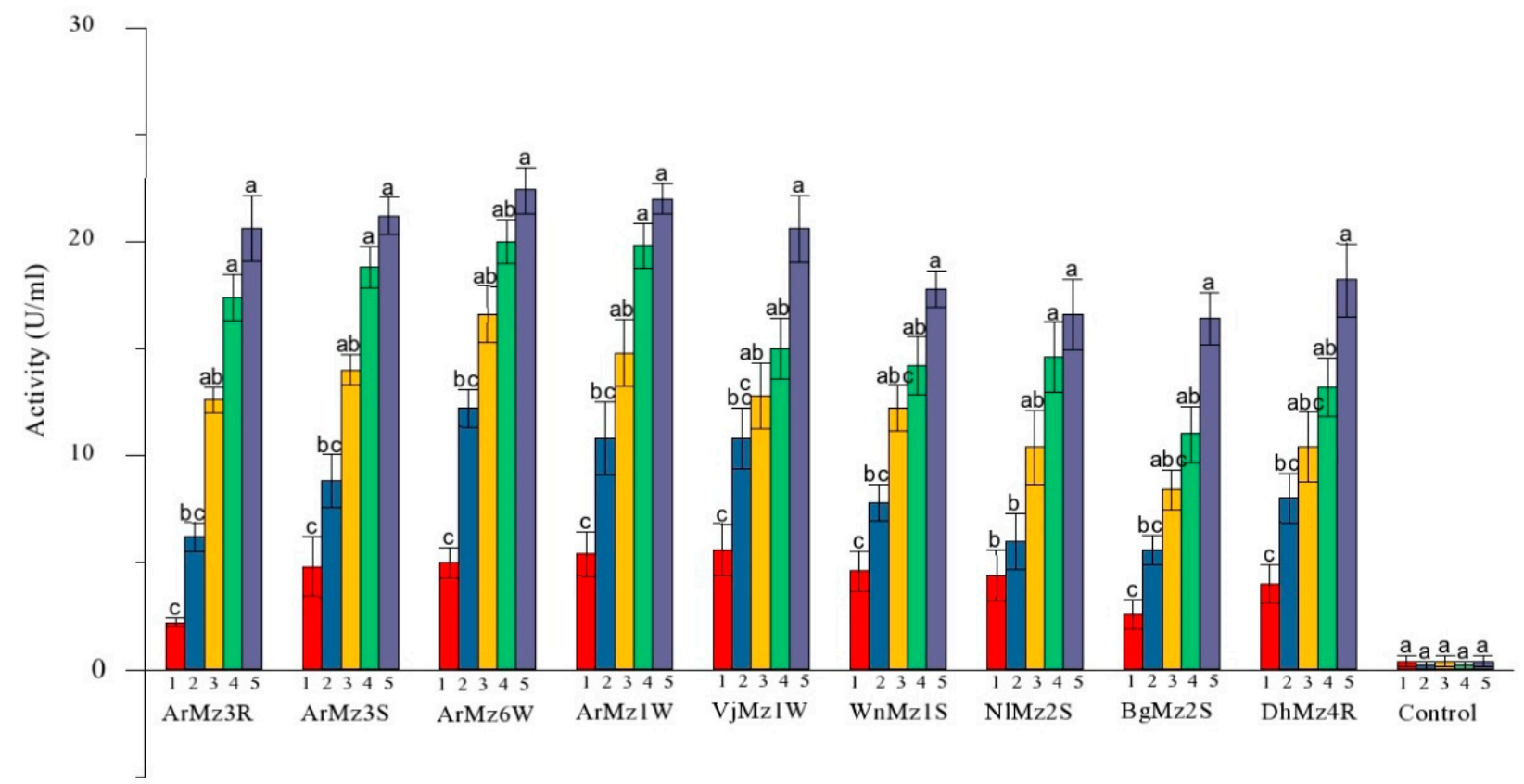

Figure 3. Activities of the proteases $(\mathrm{U} / \mathrm{mL}), \mathrm{Mean} \pm \mathrm{SE}$ in the liquid culture media of the entomopathogenic fungi in the presence of $H$. puera cuticle. Statistical differences are shown by different letters (Tukey's test, $p<0.001$ ). Each color indicating different days of incubation (1st to 5th days).

\subsection{Extracellur-Chitinases Enzymes Activity}

Chitinase activity of M. anisopliae, M. majus, M. robertsii, and M. quizhouense was varied significantly between the nine pathogenic isolates on 5 days post inoculation in chitin medium $(\mathrm{CD}(0.01)=2.684)$. The comparative analysis demonstrated that the isolates, viz., M. robertsii (ArMz3S, ArMz3R, and ArMz1W) and M. anisopliae (WnMz1S), showed statistically on par chitinase activity. The chitinase activity was found to be at its maximum during the 5th day of inoculation (Table 4; Figure 4).

Table 4. Activities of chitinase $(\mathrm{U} / \mathrm{mL})(\mathrm{Mean} \pm \mathrm{SE})$ in the liquid culture media of the entomopathogenic fungi in the presence of $H$. puera cuticle.

\begin{tabular}{|c|c|c|c|c|c|c|}
\hline \multirow{2}{*}{ Isolates } & \multicolumn{5}{|c|}{ Chitinases Enzyme Activity (U/mL) } & \multirow{2}{*}{$\begin{array}{c}\text { Comparative } \\
\text { Analysis }\end{array}$} \\
\hline & Day-1 & Day-2 & Day-3 & Day-4 & Day-5 & \\
\hline ArMz3R & $3.2 \pm 1.0^{c}$ & $6.6 \pm 1.0 \mathrm{bc}$ & $10.4 \pm 1.2^{\mathrm{abc}}$ & $15.2 \pm 1.8^{a b}$ & $21.4 \pm 1.0^{a}$ & $21.4 \pm 2.4^{\mathrm{a}}$ \\
\hline ArMz3S & $5.6 \pm 1.2^{b}$ & $8 \pm 2.5^{b}$ & $12 \pm 2.1^{\mathrm{ab}}$ & $16.4 \pm 2.1^{\mathrm{ab}}$ & $21.4 \pm 1.6^{a}$ & $21.4 \pm 3.6^{\mathrm{a}}$ \\
\hline ArMz6W & $4.6 \pm 1.0^{b}$ & $6.4 \pm 1.3^{b}$ & $8.8 \pm 1.0^{b}$ & $14 \pm 1.4^{\mathrm{ab}}$ & $21.2 \pm 1.6^{a}$ & $21.2 \pm 3.7^{a b}$ \\
\hline VjMz1W & $5.6 \pm 1.2^{a}$ & $9.6 \pm 2.1^{a}$ & $11.8 \pm 2.0^{\mathrm{a}}$ & $14.2 \pm 2.2^{\mathrm{a}}$ & $16.4 \pm 2.1^{\mathrm{a}}$ & $16.4 \pm 4.8^{\mathrm{c}}$ \\
\hline ArMz1W & $3.2 \pm 0.8^{c}$ & $8.6 \pm 2.1^{b c}$ & $14.6 \pm 2.0^{a b c}$ & $16.6 \pm 2.2^{\mathrm{ab}}$ & $21.4 \pm 1.6^{a}$ & $21.4 \pm 3.6^{a}$ \\
\hline WnMz1S & $6.4 \pm 1.2^{b}$ & $12 \pm 2.1^{\mathrm{ab}}$ & $16.8 \pm 1.8^{\mathrm{ab}}$ & $19.2 \pm 1.2^{\mathrm{a}}$ & $21.6 \pm 1.2^{\mathrm{a}}$ & $21.6 \pm 2.7^{a}$ \\
\hline NlMz2S & $6.8 \pm 1.5^{b}$ & $8.6 \pm 2.4^{b}$ & $12.6 \pm 2.6^{\mathrm{ab}}$ & $20.2 \pm 2.5^{a}$ & $21.2 \pm 1.4^{\mathrm{a}}$ & $20.2 \pm 3.3^{a b}$ \\
\hline BgMz2S & $4.4 \pm 1.0^{b}$ & $5.2 \pm 1.1^{b}$ & $7 \pm 1.3^{b}$ & $15.8 \pm 1.8^{a b}$ & $20.2 \pm 1.4^{a}$ & $20.2 \pm 3.3^{a b}$ \\
\hline DhMz4R & $4.4 \pm 1.1^{\mathrm{b}}$ & $7.4 \pm 1.2^{b}$ & $9.6 \pm 1.2^{a b}$ & $13.8 \pm 1.8^{\mathrm{ab}}$ & $19.2 \pm 1.2^{a}$ & $19.2 \pm 2.9^{b}$ \\
\hline Control & $0.4 \pm 0.2^{a}$ & $0.2 \pm 0.2^{\mathrm{a}}$ & $0.4 \pm 0.2^{a}$ & $0.2 \pm 0.2^{a}$ & $0.4 \pm 0.2^{a}$ & $0.4 \pm 0.8^{\mathrm{d}}$ \\
\hline $\mathrm{CV}$ & & & & & & 8.429 \\
\hline $\mathrm{CD}(0.01)$ & & & & & & 2.684 \\
\hline
\end{tabular}

Within the same row, mean \pm S.E.M. followed by different letters are significantly different from each other followed by adjusted Tukey test. 


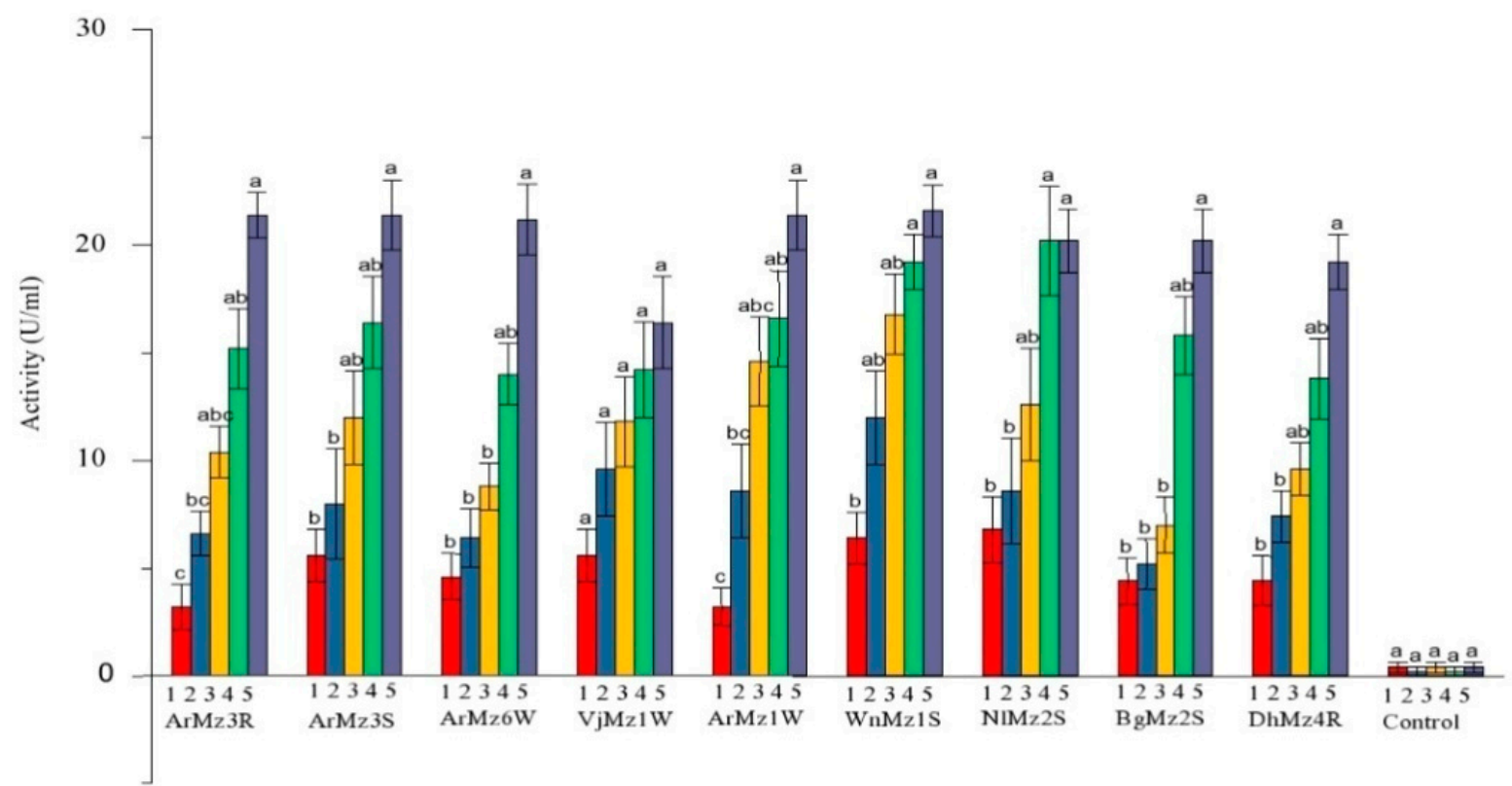

Figure 4. Activities of the chitinases $(\mathrm{U} / \mathrm{mL})$, Mean $\pm \mathrm{SE}$ in the liquid culture media of the entomopathogenic fungi in the presence of $H$. puera cuticle. Statistical differences are shown by different letters (Tukey's test, $p<0.001$ ). Each color indicating different days of incubation (1st to 5th days).

\subsection{Heat Tolerance and Cold Activity}

High variability in conidia thermo-tolerance was observed among the Metarhizium isolates. However, Metarhizium sp. isolates had a maximum germination after being exposed to cold germination temperatures at $20^{\circ} \mathrm{C}$ for 15 days in-between (26.92 to $28.22 \%$ ) for M. anisopliae (Dhz14R) and M. majus (VjMz1W), respectively. In contrast, the second high variability in cold activity was observed when conidia wasexplored at $10{ }^{\circ} \mathrm{C}$ for 15 days, with results ranging from (20.77 to $24.05 \%$ ) in M. anisopliae (DhMz4R) and M. majus (VjMz1W). Similarly conidial germination was greatly reduced at $5{ }^{\circ} \mathrm{C}$ for 15 days with the exceptions of M. anisopliae (DhMz4R) and M. majus (VjMz1W), which had approximately lower germination (Figure 5A-C).

Among the 9 Metarhizium spp., which were exposed at $45^{\circ} \mathrm{C}$ and $48^{\circ} \mathrm{C}$ for $2 \mathrm{~h}, 4 \mathrm{~h}$, $6 \mathrm{~h}, 8 \mathrm{~h}$, and $10 \mathrm{~h}$, the isolates of Metarhizium sp. varied in their conidial germination (Figures 6A-J and 7A-J). All the isolates showed progressive germination in $12 \mathrm{~h}, 24 \mathrm{~h}$, $36 \mathrm{~h}, 48 \mathrm{~h}$, and $60 \mathrm{~h}$ after exposure at $45^{\circ} \mathrm{C}$. However, at highest exposure $(60 \mathrm{~h})$, the isolates, viz., ArMz3S and ArMz6W, showed the highest conidial germination (Figure 6J).It was observed that the conidial germination was high when the incubation time increasedto $48{ }^{\circ} \mathrm{C}$ (Figure 7). At the highest exposure $(60 \mathrm{~h}$ ), the isolates, viz., M. robertsii (ArMz6W), M. quizhouense (ArMz1W), and M. majus (VjMz1W), showed the highest conidial germination (Figure 7J). 


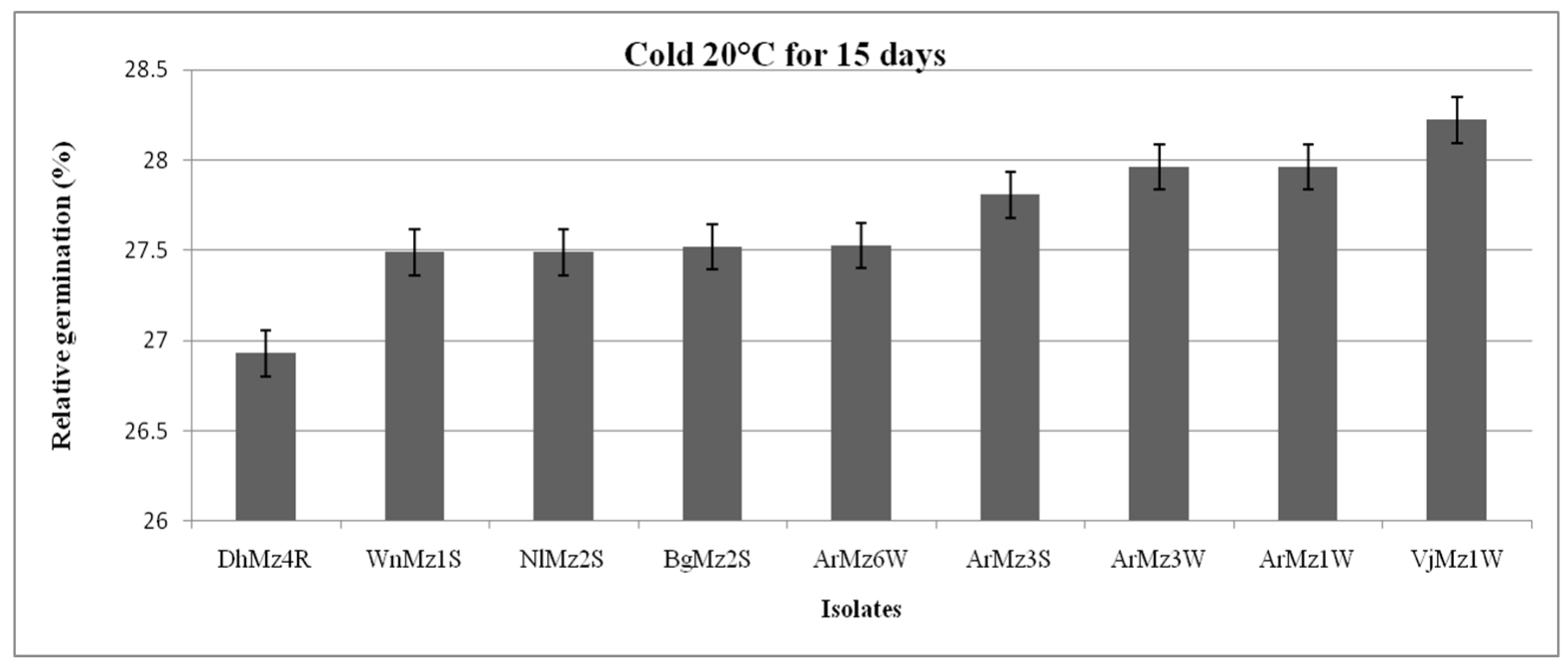

(A)

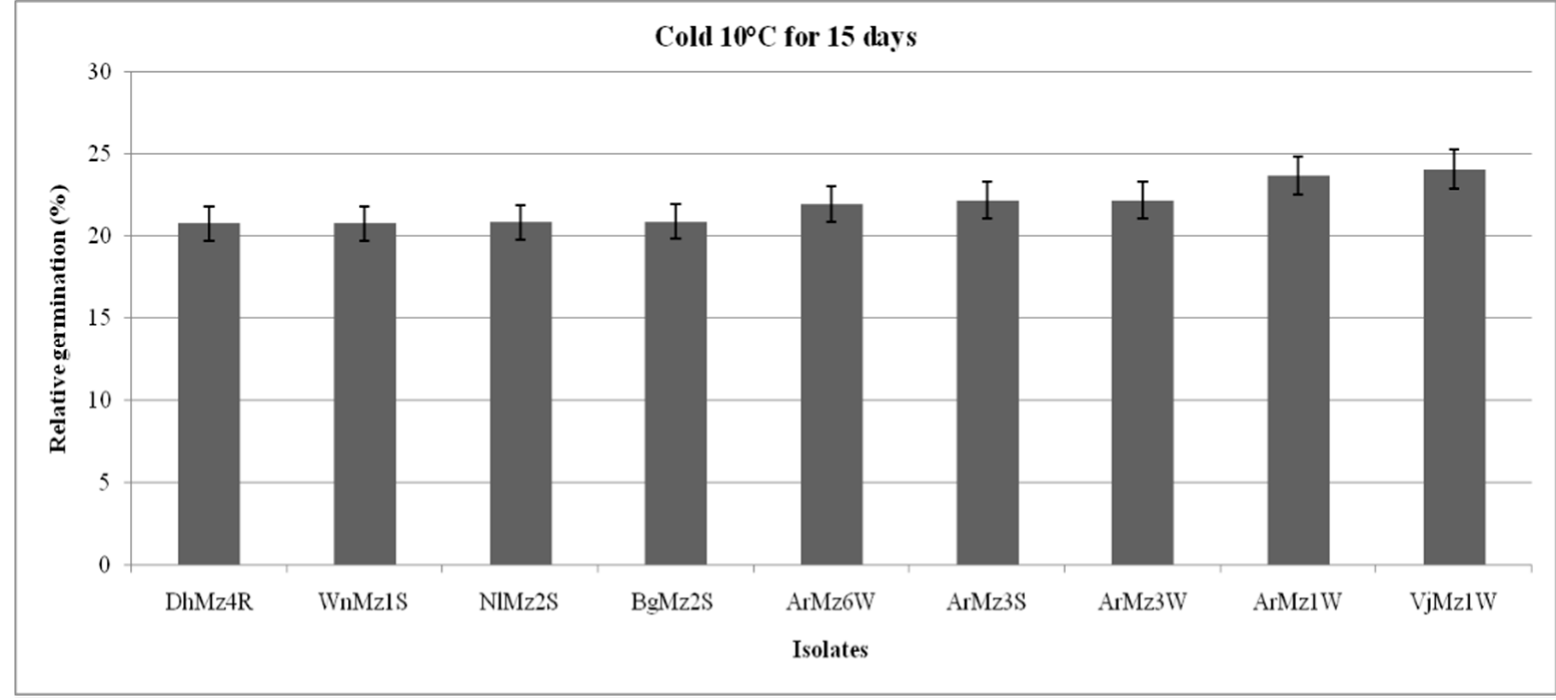

(B)

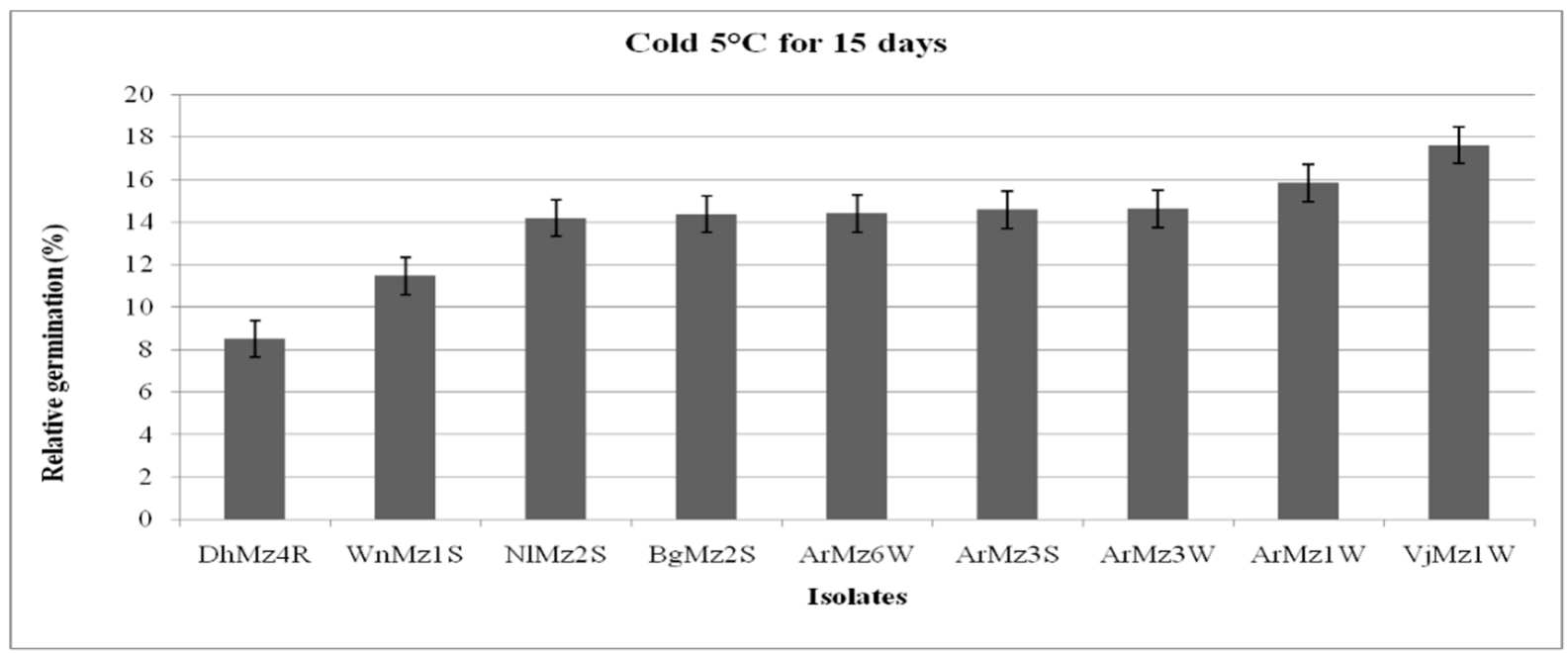

(C)

Figure 5. (A-C): Relative germination (RG) of Metarhizium spp. conidia after incubation at $5^{\circ} \mathrm{C}, 10$ ${ }^{\circ} \mathrm{C}$, and $20^{\circ} \mathrm{C}$ for 15 days. (A) At $20^{\circ} \mathrm{C}$; (B) At $10{ }^{\circ} \mathrm{C}$; (C) At $5{ }^{\circ} \mathrm{C}$. 


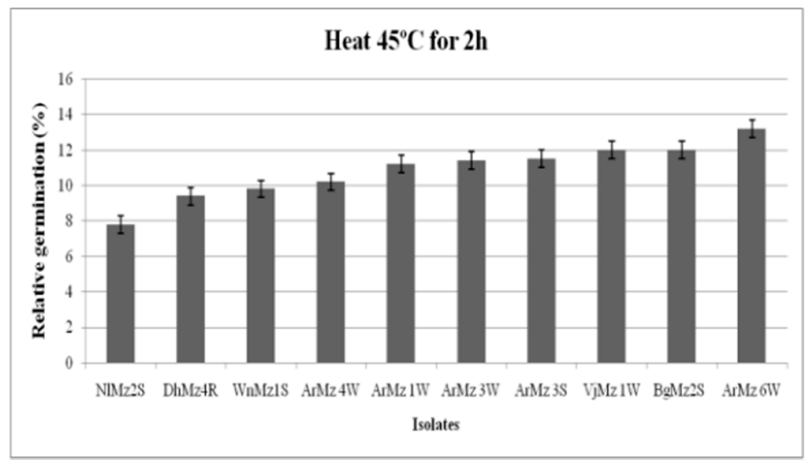

(A)

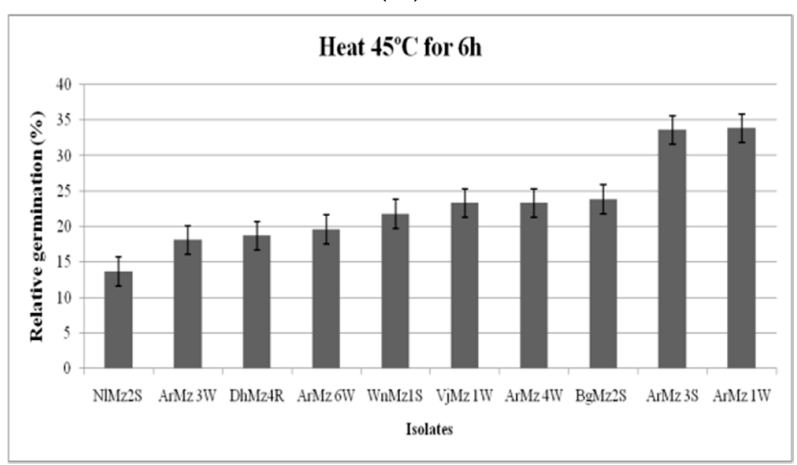

(C)

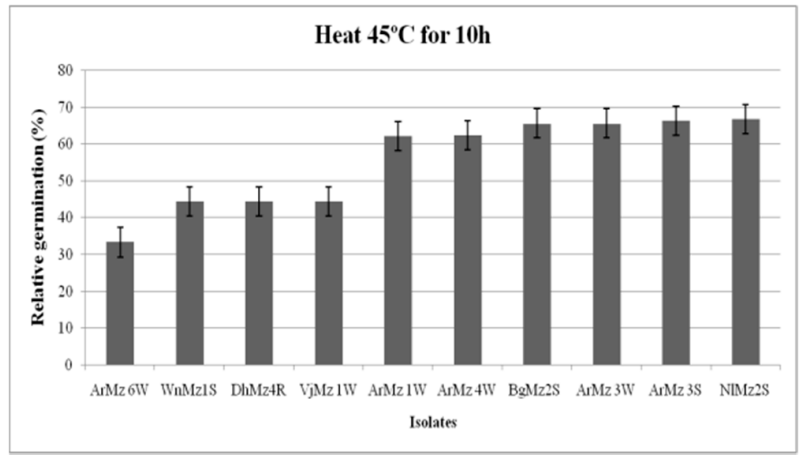

(E)

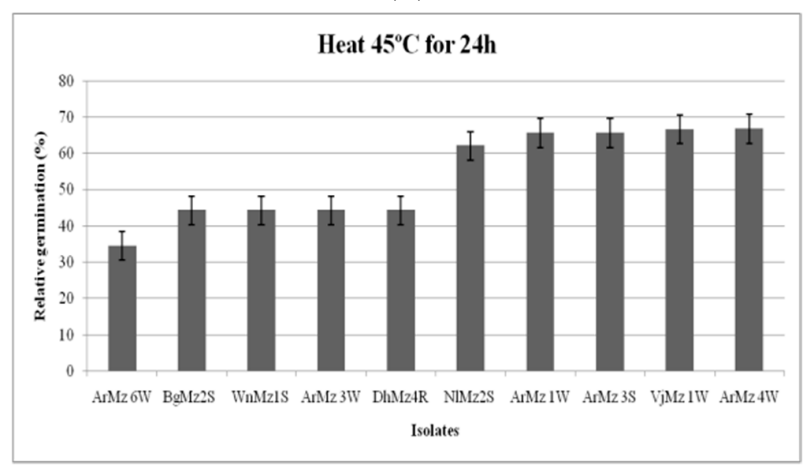

(G)

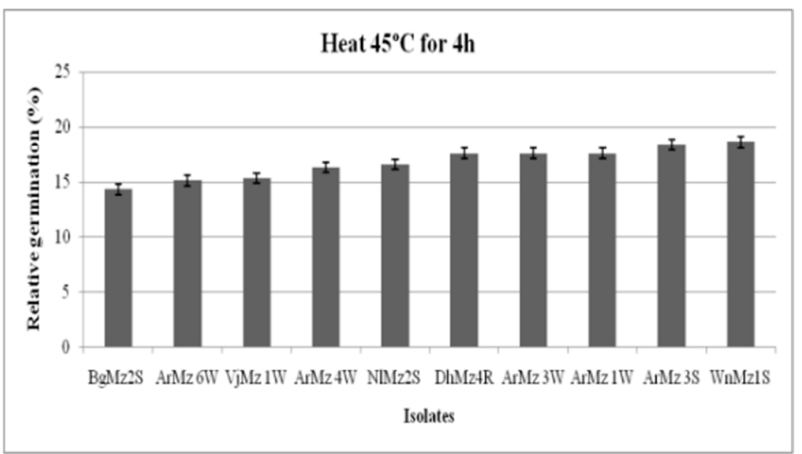

(B)

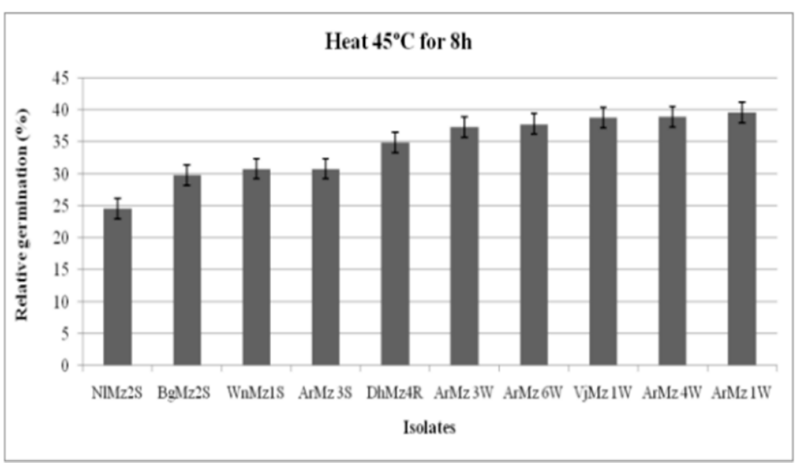

(D)

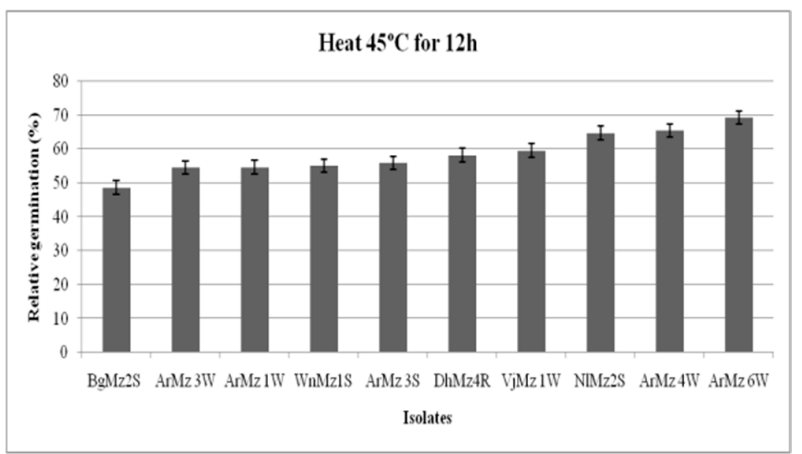

(F)

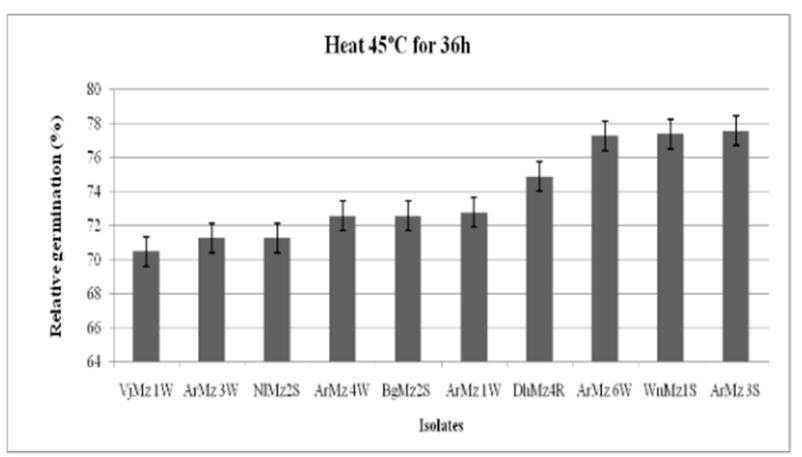

(H)

Figure 6. Cont. 


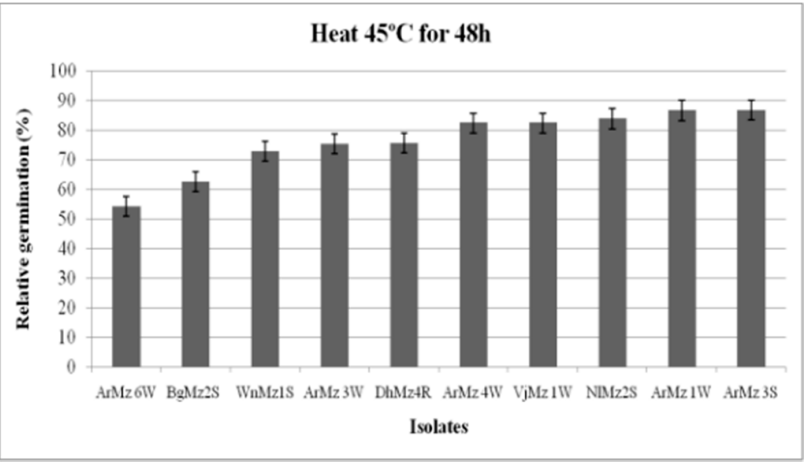

(I)

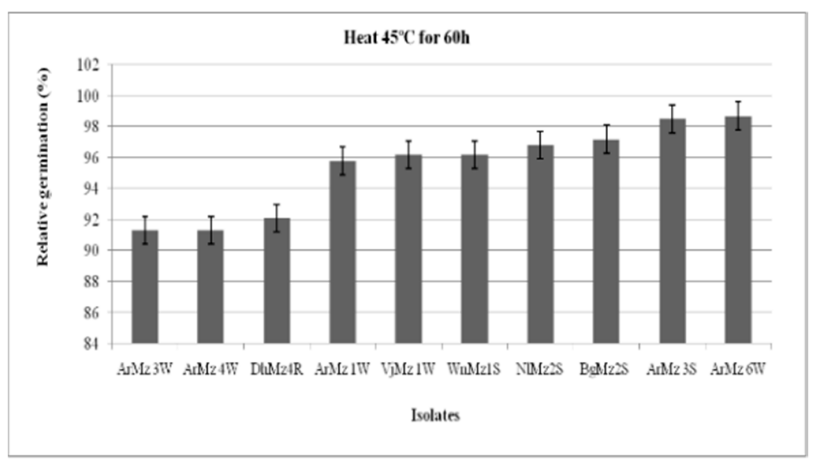

(J)

Figure 6. Relative germination of different isolates of Metarhizium sp., exposed at $45^{\circ} \mathrm{C}$. Relative germination (RG) of Metarhizium spp. conidia exposed for (A) $2 \mathrm{~h}$, (B) $4 \mathrm{~h}$, (C) $6 \mathrm{~h}$, (D) $8 \mathrm{~h}$, (E) $10 \mathrm{~h}$, (F) $12 \mathrm{~h},(\mathbf{G}) 24 \mathrm{~h},(\mathbf{H}) 36 \mathrm{~h},(\mathbf{I}) 48 \mathrm{~h}$, and (J) $60 \mathrm{~h}$. RG was calculated in relation to non-heated controls.

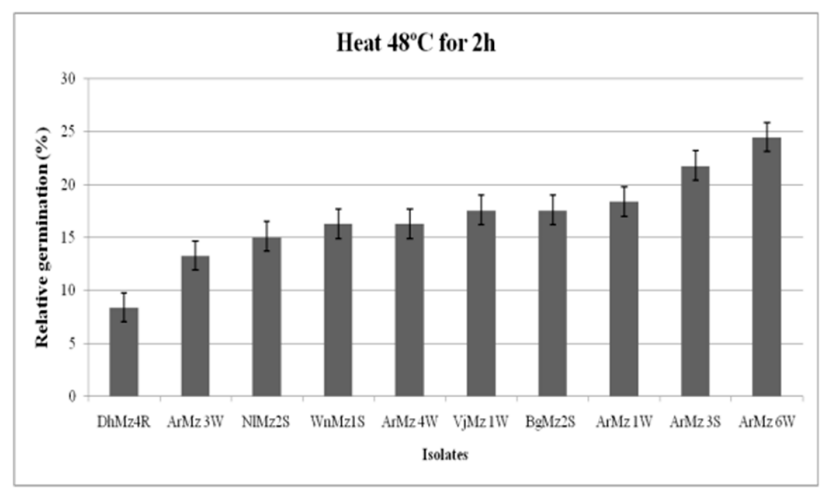

(A)

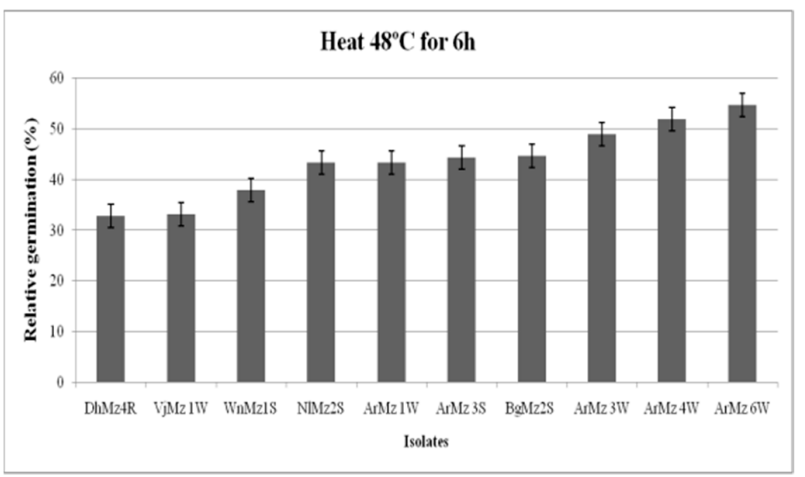

(C)

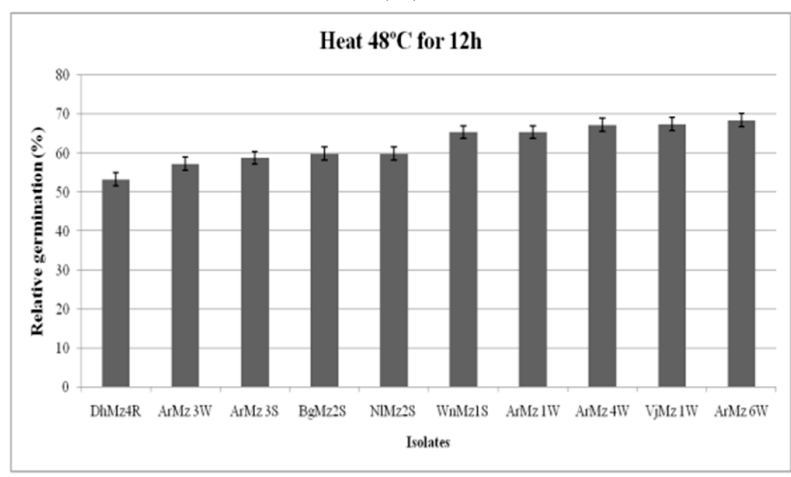

(E)

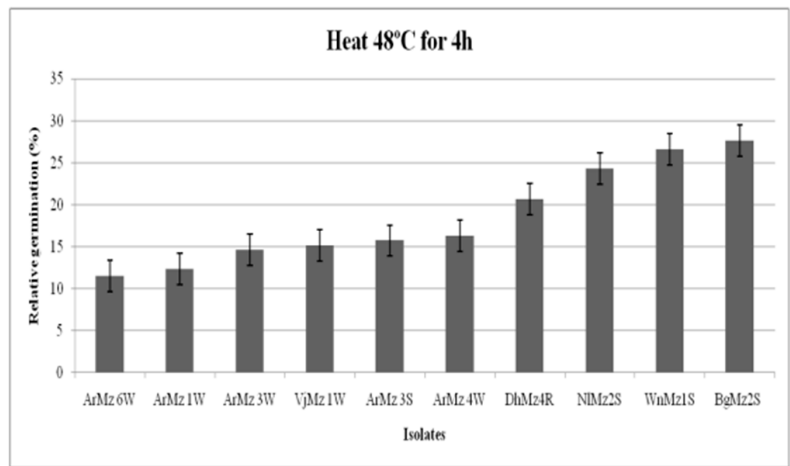

(B)

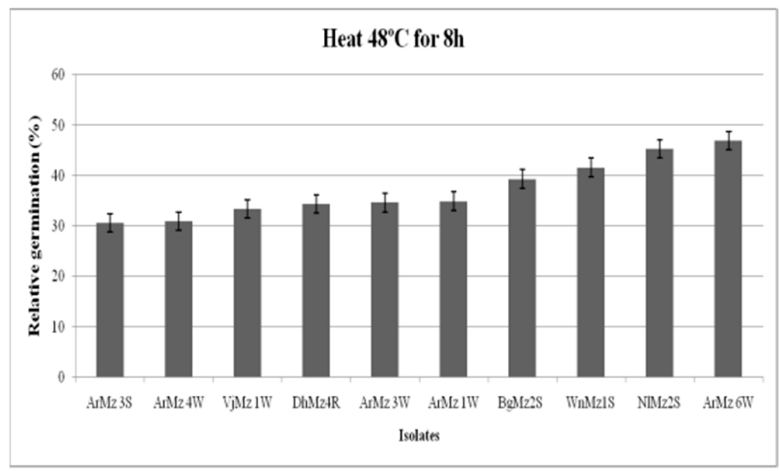

(D)

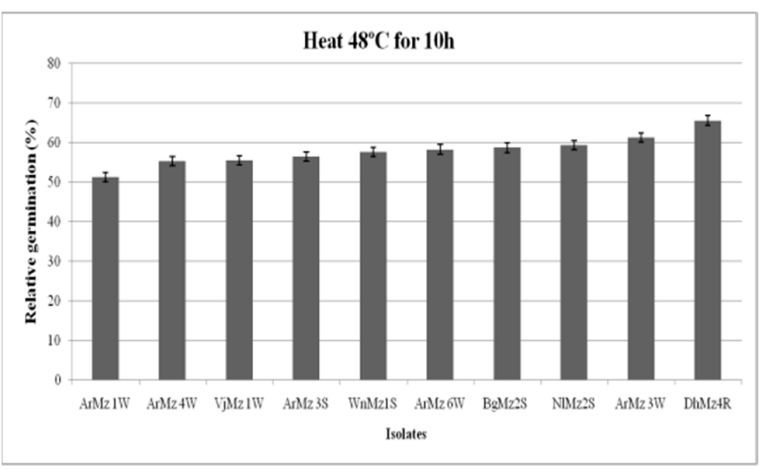

(F)

Figure 7. Cont. 


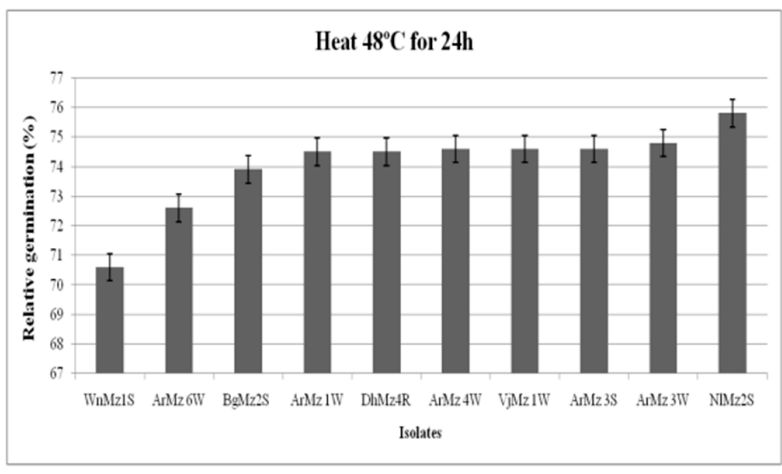

(G)

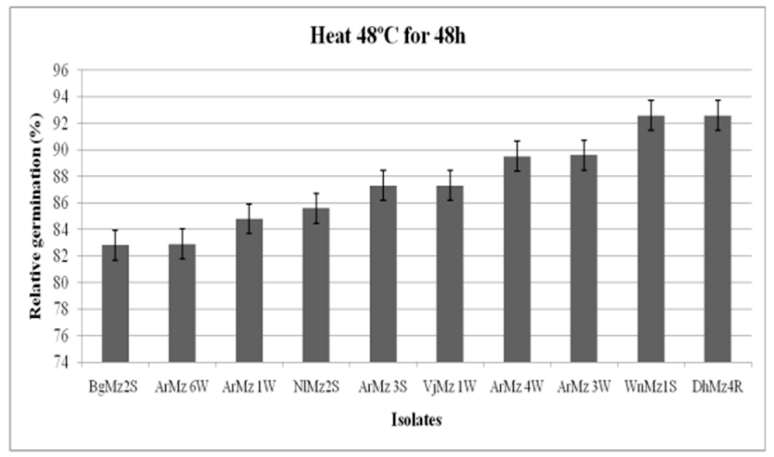

(I)

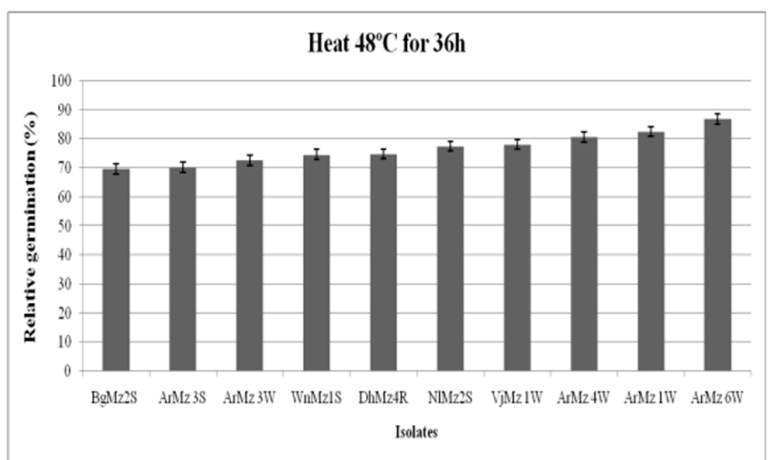

(H)

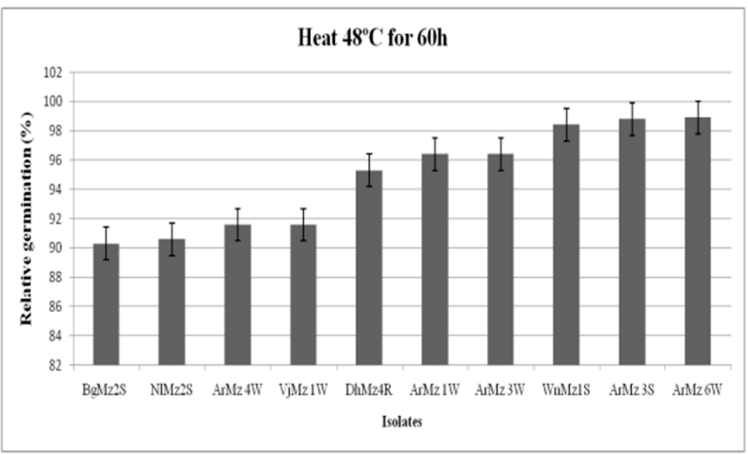

(J)

Figure 7. Relative germination of different isolates of Metarhizium sp. exposed at $48{ }^{\circ} \mathrm{C}$. Relative germination (RG) of Metarhizium spp. conidia exposed for (A) $2 \mathrm{~h}$, (B) $4 \mathrm{~h},(\mathrm{C}) 6 \mathrm{~h},(\mathrm{D}) 8 \mathrm{~h}$, (E) $10 \mathrm{~h}$, (F) $12 \mathrm{~h},(\mathrm{G}) 24 \mathrm{~h},(\mathbf{H}) 36 \mathrm{~h},(\mathrm{I}) 48 \mathrm{~h}$, and (J) $60 \mathrm{~h}$. RG was calculated in relation to non-heated controls.

\section{Discussion}

The identification was done on the basis of morphotaxonomic characters revealed by microscopically inspecting the conidia forming mycelia for conidigenious structure. Each isolate was put into regular host passages using the natural hosts on three species of M. anisopliae, M. robertsii, and M. majus isolate [2,3]. The effect of visible light during mycelia growth factor on the stress tolerance may exhibit an enhanced protein metabolism as suggested by the conidia $[7,11,38]$.

In the present study, nine isolates of Metarhizium sp. were characterized for thermal tolerance and cold activity.For cold activity, the isolates were exposed to low temperature, viz., 5, 10, and $20^{\circ} \mathrm{C}$. M. majus (VjMz1W) showed higher conidial germination in all the cold temperatures. An earlier study reported that the Metarhizium sp., viz., M. flavoviridae and $M$. frigidium, were able to tolerate the cold temperature and produced conidia at the lowest temperature of their experiments $\left(5^{\circ} \mathrm{C}\right)$.

The heat tolerance of isolates of Metarhizium sp. was tested at the higher temperatures of 45 and $48{ }^{\circ} \mathrm{C}$ in different exposure times $(2,4,6,8,10,12,24,36,48$ and $60 \mathrm{~h})$. The temperature tolerance was increased when the exposure time increased. In both of the heat temperatures, M. robertsii (ArMz6W) showed high conidial germination at $60 \mathrm{~h}$ after exposure. Earlier studies reported that the isolates of $M$. anisopliae var. acridium (ARSEF 6421, ARSEF 3614, ARSEF 5736, ARSEF 324, and ARSEF 2341) were most conidial heat tolerant at higher temperatures $\left(45^{\circ} \mathrm{C}\right)[6,7,15,40,41]$.

In the present investigation, chitinase and protease were found to show high correlation with mortality. Earlier literature has been reported that chitinases and proteases were the virulence factors for entomopathogenicity $[19,42]$. The hydrophobicity of conidia is one of the important parameters influencing fungus-insect interaction as it helps in adhesion of the fungus to the insect cuticle. This plays an important role in providing nutrients before and after the cuticle is penetrated $[20,21]$. However, chitinase is required only for a brief 
period during penetration of the host cuticle and is tightly regulated by chitin degradation products $[22,23,33]$. The fungus produces spores, which, upon germination, produce young germ tubes that penetrate through the cuticle, physically as well as chemically through the enzymes produced, such as proteases, chitinases, and lipases [43-47].

The insecticidal mechanism underlying in the pathogenicity of isolated fungi lies in presence of cuticle degrading enzymes which make paves way for the entry of EPF in the insect body [48-52]. To invade the insect cuticle, which is mainly composed of chitin and several other proteins, entomopathogens must secrete chitinase and protease enzymes [53-58]. Mechanism of enzymatic degradation of larval cuticle for hyphal penetrance by this fungus inside larval body is confirmed by the detection of chitinase and protease enzymes thatare secreted by the fungi.

Our study showed that the isolates of Metarhizium sp., viz., M.anisopliae (DhMz4R), M. quizhouense (ArMz1W), and M. majus (VjMz1W), showed higher pathogenicity $(94.4 \pm 2.03$, $92 \pm 4.19$, and $90.8 \pm 3.2$ percent mortality, respectively) at $10^{6}$ conidia/mL. Similarly, Ramadevi et al. [59] conducted the bioassay experiment to test virulence of M. anisopliae (MIS2 and MIS7) against H. puera. They found less percent mortality compared to the present study isolates.

The four species of Metarhizium spp., viz., M. anisopliae, M. robertsii, M. quizhouense, and M. majus, were obtained from insects infected and soil baiting methods. Therefore, EPF isolates revealed that for different parts of South India, indigenous isolates showed thebest mortality against 3rd instar larvae $H$. puera in the range of $84-92 \%$ within 5 days. Our results have indicated that three species, viz., M. robertsii, M. quizhouense, and M. majus, isolates were recorded for the first time and they had comparatively significantly higher mortality rates.

\section{Conclusions}

This study has revealed that M. anisopliae, M. robertsii, M. quizhouense, and M. majus are exceptionally effective and can be considered some of the best EPF isolates. Further investigation to control the infestation of teak defoliator $H$. puera should be performed on plantations in South India. The development of a possible new bio-control agent forthe invasive teak defoliator $H$. puera pest is now possible with a better understanding ofthe potential use of indigenous entomopathogenic fungi.

Author Contributions: Conceptualization, V.V. and R.D.; methodology, validation, V.V. and O.A.N and G.R., S.K. and S.S.-N.; formal analysis; V.V.; writing-review and editing, E.J.K., O.A.N., R.D., S.K., S.S.-N. and G.R. All authors have read and agreed to the published version of the manuscript.

Funding: This research received no external funding.

Institutional Review Board Statement: Not applicable.

Informed Consent Statement: Not applicable.

Data Availability Statement: All the relevant data are included within the manuscript.

Acknowledgments: The authors are highly thankful to R. Rangeshwaran, G. Sivakumar Principal Scientist, (ICAR-National Bureau of Agricultural Insect Resources), T.O. Sasidharan and R. Sundararaj, Scientist G (Institute of Wood Science and Technology, Forest and wood protection) for valuable suggestion for identification of entomopathogenic fungi. The author grateful to the R.Karthi at ICAR-National Research Center for Banana, for Tukey analysis (Graph was generated using OriginLab Professional Version 2021b software; URL link: https:/ /www.originlab.com/, accessed on 29 September 2021).

Conflicts of Interest: The authors declare no conflict of interest. 


\begin{abstract}
Abbreviations
EPF Entomopathogenic Fungi

PDAY Potato Dextrose Agar with Yeast extract

SDAY Sabouraud Dextrose Agar with Yeast extract

ITS ribosomal internal transcribed spacer

RPB1 DNA-directed RNA polymerase II subunit
\end{abstract}

\title{
References
}

1. Metchnikoff, E. Diseases of the larva of the grain weevil. In Insects Harmful to Agriculture; Odessa Zemstvo Office: Odessa, Ukraine, 1879. (In Russian)

2. Bischoff, J.F.; Rehner, S.A.; Humber, R.A. A multilocus phylogeny of the Metarhizium anisopliae lineage. Mycologia 2009, 101, 512-530. [CrossRef]

3. Kepler, R.M.; Humber, R.A.; Bischoff, J.F.; Rehner, S.A. Clarification of generic and species boundaries for Metarhizium and related fungi through multigenephylogenetics. Mycologia 2014, 106, 811-829. [CrossRef]

4. Chandra Teja, K.N.; Pand Rahman, S.J. Characterisation and evaluation of Metarhizium anisopliae (Metsch.) Sorokin strains for their temperature tolerance. Mycology 2016, 7, 171-179. [CrossRef] [PubMed]

5. Keyser, C.A.; Fernandes, É.K.K.; Rangel, D.E.N.; Roberts, D.W. Heat-induced post-stress growth delay: A biological trait of many Metarhizium isolates reducing biocontrol efficacy. J. Invertebr. Pathol. 2014, 120, 67-73. [CrossRef] [PubMed]

6. Rangel, D.E.N.; Fernandes, E.K.K.; Dettenmaier, S.J.; Roberts, D.W. Thermotolerance of germlings and mycelium of the insectpathogenic fungus Metarhizium spp. and mycelial recovery after heat stress. J. Basic. Microbiol. 2010, 50, 344-350. [CrossRef]

7. Fernandes, E.K.K.; Keyser, C.A.; Chong, J.P.; Rangel, D.E.N.; Miller, M.P.; Roberts, D.W. Characterization of Metarhizium species and varieties based on molecular analysis, heat tolerance and cold activity. J. App. Microbiol. 2010, 108, 115-128. [CrossRef] [PubMed]

8. Hunt, V.L.; Zhong, W.; McClure, C.D.; Mlynski, D.T.; Duxbury, E.M.L.; Keith Charnley, A.; Priest, N.K. Cold-seeking behaviour mitigates reproductive losses from fungal infection in Drosophila. J. Anim. Ecol. 2016, 85, 178-186. [CrossRef]

9. Ibrahim, L.; Butt, T.M.; Jenkinson, P. Effect of Artificial Culture Media on Germination, Growth, Virulence and Surface Properties of the Entomopathogenic Hyphomycete (Metarhizium anisopliae). Myco. Res. 2002, 106, 705715. [CrossRef]

10. Inglis, G.D.; Duke, G.M.; Kawchuk, L.M.; Goettel, M.S. Influence of oscillating temperatures on the competitive infection and colonization of the migratory grasshopper by Beauveria bassiana and Metarhizium flavoviride. Biol. Control. 1999, 14, 111-120. [CrossRef]

11. Nishi, O.; Hasegawa, K.; Iiyama, K.; Yasunaga-Aoki, C.; Shimizu, S. Phylogenetic analysis of Metarhizium spp. isolated from soil in Japan. Appl. Entomol. Zool. 2011, 46, 301-309. [CrossRef]

12. Lekime, M.; Focant, C.; Farnir, F.; Mignon, B.; Losson, B. Pathogenicity and Theromotolerance of Entomopathogenic Fungi for the Control of the Scab Mite, Psoroptesovis. Exp. Appl. Acarol. 2008, 46, 95-104. [CrossRef] [PubMed]

13. Bidochka, M.J.; Kamp, A.M.; Lavender, T.M.; Dekoning, J.; De Croos, J.N. Habitat association in two genetic groups of the insect-pathogenic fungus Metarhizium anisopliae: Uncovering cryptic species. Appl. Environ. Microbiol. 2001, 67, 1335-1342. [CrossRef] [PubMed]

14. Braga, G.U.L.; Flint, S.D.; Messias, C.L.; Anderson, A.J.; Roberts, D.W. Effect of UV-B on conidia and germlings of the entomopathogenic hyphomycete Metarhizium anisopliae. Mycol. Res. 2001, 105, 874-882. [CrossRef]

15. Rangel, D.E.N.; Anderson, A.J.; Roberts, D.W. Evaluating physical and nutritional stress during mycelial growth as inducers of tolerance to heat and UV-B radiation in Metarhizium anisopliae conidia. Mycol. Res. 2008, 112, 1362-1372. [CrossRef]

16. Liu, H.; Skinner, M.; Brownbridge, M.; Parker, B.L. Characterization of Beauveria bassiana and Metarhizium anisopliae isolates for management of tarnished plant bug, Lygus lineolaris (Hemiptera: Miridae). J. Invertebr. Pathol. 2003, 82, 139-147. [CrossRef]

17. Hegedus, D.D.; Khachatourians, G.G. The impact of biotechnology on hyphomycetous fungal insect biocontrol agents. Biotechnol. Adv. 1995, 13, 455-490. [CrossRef]

18. Krieger de Moraes, C.; Schrank, A.; Vainstein, M.H. Regulation of extracellular chitinases and proteases in the entomopathogen and acaricides Metarhizium anisopliae. Curr. Microbiol. 2003, 46, 205-210. [CrossRef]

19. St. Leger, R.J.; Bidochka, M.J.; Roberts, D.W. Construction of an improved mycoinsecticide over expressing a toxic protease. Proc. Natl. Acad. Sci. USA 1996, 93, 6349-6354. [CrossRef]

20. Nahar, P.; Ghormade, V.; Deshpande, M.V. The extracellular constitutive production of chitin deacetylase in Metarhizium anisopliae: Possible edge to entomopathogenic fungi in the biological control of insect pests. J. Invertebr. Pathol. 2004, 85, 80-88. [CrossRef]

21. Revathi, N.; Ravikumar, G.; Kalaiselvi, M.; Gomathi, D.; Uma, C. Pathogenicity of three entomopathogenic fungi against Helicoverpa armigera. J. Plant Pathol. Microbiol. 2011, 2, 114. [CrossRef]

22. Sapna Bai, N.; Remadevi, O.K.; Sasidharan, T.O.; Balachander, M.; Priyadarsanan, D.R. Cuticle degrading enzyme production by some isolates of the Entomopathogenic fungus, Metarhizium anisopliae (Metsch). J. Bio-Sci. 2012, 20, 25-32.

23. Ramanujam, B.; Balachander, M.; Roopa, G.; Rangeshwaran, R.; Karmakar, P. Chitinase activity and virulence of different isolates of Beauveria bassiana, Metarhizium anisopliae and Lecanicillium spp. J. Biol. Control 2011, 25, 223-228. 
24. Beeson, C.F.C. The Ecology and Control of the Forest Insects of India and the Neighboring Countries; Government of India: New Delhi, India, 1941; p. 767.

25. Sudheendrakumar, V.V.; Mohammed Ali, I.M.; Varma, R.V. Nuclear Polyhedrosis Virus of the teak defoliator Hyblaeapuera. J. Invert. Pathol. 1988, 51, 307-308. [CrossRef]

26. Senthil-Nathan, S.; Saehoon, K. Behavioral and physiological effects of Melia azedarach L. extract on the teak defoliator Hyblaeapuera Cramer (Lepidoptera: Hyblaeidae). Crop Prot. 2006, 25, 287-291. [CrossRef]

27. Senthil-Nathan, S. A Review of Bio Pesticides and Their Mode of Action against Insect Pests. In Environmental Sustainability-Role of Green Technologies; Springer: Dordrecht, The Netherlands, 2015; pp. 49-63.

28. Velavan, V.; Sivakumar, G.; Rangeswaran, R.; Sasidharan, T.O.; Sundararaj, R. Metarhiziummajus and Metarhiziumrobertsii show enhanced activity against the coleopteran pests Holotricha serrata L. and Oryctes rhinoceros L. J. Biol. Control 2017, 31, 135-145. [CrossRef]

29. Veen, K.H.; Ferron, P. A selective medium for the isolation of Beauveria tenella and of Metarhiziumanisopliae. J. Invertebr. Pathol. 1966, 8, 268-269. [CrossRef]

30. Riddell, R.W. Permanent stained mycological preparations obtained by slide culture. Mycologia 1950, 42, 265-270. [CrossRef]

31. Senthil-Nathan, S.; Choi, M.Y.; Paik, C.H.; Seo, H.Y. Food consumption, utilization, and detoxification enzyme activity of the rice leaffolder larvae after treatment with Dysoxylum triterpenes. Pest. Biochem. Physiol. 2007, 88, 260-267. [CrossRef]

32. Remadevi, O.K.; Sasidharan, T.O.; Balachander, M.; Sapna Bai, N. Prospects of developing Metarhizium based mycoinsecticide for pest management in forestry. J. Biopestic. 2010, 3, 38-41.

33. Dhar, P.; Kaur, G. Cuticle-Degrading Proteases Produced by Metarhizium anisopliae and Their Induction in Different Media. Indian J. Microbiol. 2010, 50, 449-455. [CrossRef]

34. Kulkarni, S.A.; Ghormade, V.; Kulkarni, G.; Kapoor, M.; Chavan, S.B.; Rajendran, A.; Patil, S.K.; Shouche, Y.; Deshpande, M.V. Comparison of Metarhizium isolates for biocontrol of Helicoverpa armigera (Lepidoptera: Noctuidae) in chickpea. Biocontrol. Sci. Technol. 2008, 18, 809-828. [CrossRef]

35. Senthil-Nathan, S. Physiological and biochemical effect of Neem and other Meliaceae plants secondary metabolites against Lepidopteran insects. Front. Physiol. 2013, 4, 359. [CrossRef] [PubMed]

36. Jha, S.C. Modi Comparative Analysis of Chitinase Activity by Four Different Assays from Soil Born Actinomycetes. In Proceedings of the 4th International Conference on Multidisciplinary Research \& Practice (4ICMRP) Gujarat University, Ahmedabad, India, 22 December 2017; pp. 185-190.

37. Milner, R.J.; Huppatz, R.J.; Swaris, S.C. A new method for assessment of germination of Metarhizium conidia. J. Invertebr. Pathol. 1991, 57, 121-123. [CrossRef]

38. Braga, G.U.L.; Flint, S.D.; Miller, C.D.; Anderson, A.J.; Roberts, D.W. Variability in response to UV-B among species and strains of Metarhizium isolated from sites at latitudes from 61N to 54 S. J. Invertebr. Pathol. 2001, 78, 98-108. [CrossRef]

39. Velavan, V.; Rangeshwaran, R.; Sivakumar, G.; Sasidharan, T.O.; Sundararaj, R.; Kandan, A. Occurrence of Metarhizium spp. isolated from forest soils in South India and their potential in biological control of banana stem weevil Odoiporus longicollis Oliver. Egypt. J. Biol. Pest Control 2021, 31, 131-143. [CrossRef]

40. Lee, W.W.; Shin, T.Y.; Bae, S.M.; Woo, S.D. Screening and evaluation of entomopathogenic fungi against the green peach aphid, Myzus persicae, using multiple tools. J. Asia Pac. Entomol. 2015, 18, 607-615. [CrossRef]

41. Li, J.; Feng, M.G. Intra specific tolerance of Metarhizium anisopliae conidia to the upper thermal limits of summer with a description of a quantitative assay system. Mycol. Res. 2009, 113, 93-99. [CrossRef] [PubMed]

42. Rangel, D.E.N.; Anderson, A.J.; Roberts, D.W. Growth of Metarhizium anisopliae on non-preferred carbon sources yields conidia with increased UV-B tolerance. J. Invertebr. Pathol. 2006, 93, 127-134. [CrossRef]

43. Vasantha-Srinivasan, P.; Karthi, S.; Chellappandian, M.; Ponsankar, A.; Thanigaivel, A.; Senthil-Nathan, S.; Chandramohan, D.; Ganesan, R. Aspergillus flavus (Link) toxins reduces the fitness of dengue vector Aedes aegypti (Linn.) and their non-target toxicity against aquatic predator. Microb. Pathog. 2019, 128, 281-287. [CrossRef] [PubMed]

44. Karthi, S.; Vasantha-Srinivasan, P.; Ganesan, R.; Ramasamy, V.; Senthil-Nathan, S.; Khater, H.F.; Radhakrishnan, N.; Amala, K.; Kim, T.J.; El-Sheikh, M.A.; et al. Target Activity of Isaria tenuipes (Hypocreales: Clavicipitaceae) Fungal Strains against Dengue Vector Aedes aegypti (Linn.) and Its Non-Target Activity Against Aquatic Predators. J. Fungi. 2020, 6, 196. [CrossRef]

45. Nishi, O.; Iiyama, K.; Yasunaga-Aoki, C.; Shimizu, S. Comparison of the germination rates of Metarhizium spp. conidia from Japan at high and low temperatures. Lett. Appl. Microbiol. 2013, 57, 554-560. [CrossRef]

46. Gurvinder, K.; Padmaja, V. Relationships among activities of extracellular enzyme production and virulence against Helicoverpa armigera in Beauveria bassiana. J. Basic Microbiol. 2009, 49, 264-274.

47. Charnley, A.K.; St. Leger, R.J. The Role of Cuticle Degrading Enzymes in Fungal Pathogenesis of Insects. In The Fungal Spore and Disease Initiation in Plants and Animals; Plenum Publishing Co.: New York, NY, USA, 1991; pp. 267-286.

48. St. Leger, R.J.; Cooper, R.M.; Charnley, A.K. Cuticle-degrading enzymes of entomopathogenic fungi: Cuticle degradationin vitro by enzymes from entomopathogens. J. Invertebr. Pathol. 1986, 47, 167-177. [CrossRef]

49. Dhanapal, R.; Kumar, D.V.S.R.; Lakshmipathy, R.; Sandhya Rani, C.; Manoj Kumar, R. Pathogenicity testing of indigenous isolates of entomopathogenic fungus, Lecanicillium lecanii against tobacco caterpillar, Spodoptera litura. J. Experi. Zool. India 2019, $22,753-756$. 
50. Dhanapal, R.; Kumar, D.V.S.R.; Lakshmipathy, R.; Sandhya Rani, C.; Manoj Kumar, R. Exploration of indigenous strains of the green muscardine fungus from soils and their pathogenicity against the tobacco caterpillar, Spodoptera litura (Fabricius) (Lepidoptera: Noctuidae). Egypt. J. Biol. Pest Control 2020, 30, 34. [CrossRef]

51. Dhanapal, R.; Kumar, D.V.S.R.; Lakshmipathy, R.; Sandhya Rani, C.; Manoj Kumar, R. Isolation of indigenous strains of the white halo fungus as a biological control agent against 3rd instar larvae of tobacco caterpillar, Spodoptera litura (Fabricius) (Lepidoptera: Noctuidae). Egypt. J. Biol. Pest Control 2020, 30, 89. [CrossRef]

52. Karthi, S.; Vaideki, K.; Shivakumar, M.S.; Ponsankar, A.; Thanigaivel, A.; Chellappandian, M.; Vasantha-Srinivasan, P.; Chanthini, K.M.; Hunter, W.B.; Senthil-Nathan, S. Effect of on the mortality of Aspergillus flavus and activity of antioxidant enzymes of Spodoptera litura Fab. (Lepidoptera: Noctuidae) larvae. Pestic. Biochem. Physiol. 2018, 149, 54-60. [CrossRef] [PubMed]

53. Ghosh, S.K.; Podder, D.; Mukherjee, A. An insight of anopheline larvicidal mechanism of Trichoderma asperellum (TaspSKGN2). Sci. Rep. 2021, 11, 16029. [CrossRef] [PubMed]

54. Kirubakaran, S.A.; Senthil-Nathan, S.; Revathi, K.; Chandrasekaran, R.; Senthil-Nathan, S. Effect of oil-formulated Metarhiziumanisopliae and Beauveria bassiana against the rice leaffolder Cnaphalocrocis medinalis Guenée (Lepidoptera: Pyralidae). Arch. Phytopathol. Plant Prot. 2014, 47, 977-992. [CrossRef]

55. Sangeetha, A.; Arivudainambi, S. Studies on the efficacy of bio-products in the management of teak skeletonizer Eutectonamachaeralis Walker (Pyralidae: Lepidoptera). J. Biopest. 2012, 5, 129-134.

56. Loganathan, J.; David, P.M.M. Laboratory and field evaluation of Bacillus thuriengiensis Berliner products against the teak defoliator Hyblaea puera Cramer. Insect. Sci. Appl. 2000, 20, 61-65.

57. Biji, C.P.; Sudheendrakumar, V.V.; Sajeev, T.V. Quantitative estimation of Hyblaea puera NPV production in three larval stages of the teak defoliator, Hyblaea puera (Cramer). J. Virol. Meth. 2006, 136, 78-82. [CrossRef]

58. Narayanan, K. Insect defence: Its impact on microbial control of insect pests. Curr. Sci. 2004, 86, 800-814.

59. Remadevi, O.K.; SapnaBai, N.; Sasidharan, T.O.; Balachander, M.; Dharmarajan, P. Attempts at controlling Teak Defoliator (Hyblaea puera Cramer, Lepidoptera, Hyblaeidae) with the entomopathogenic fungus, Metarhizium anisopliae (Metsch.): Laboratory, nursery and field trials. Int. J. Pest Manag. 2013, 59, 236-242. [CrossRef] 